\title{
Making patient blood management the new norm(al) as experienced by implementors in diverse countries
}

\author{
Axel Hofmann ${ }^{1,2+}$, Donat R. Spahn ${ }^{1 \dagger}$, Anke-Peggy Holtorf ${ }^{3,4^{*}+}$ (D) and PBM Implementation Group
}

\begin{abstract}
Background: Patient blood management (PBM) describes a set of evidence-based practices to optimize medical and surgical patient outcomes by clinically managing and preserving a patient's own blood. This concepts aims to detect and treat anemia, minimize the risk for blood loss and the need for blood replacement for each patient through a coordinated multidisciplinary care process. In combination with blood loss, anemia is the main driver for transfusion and all three are independent risk factors for adverse outcomes including morbidity and mortality. Evidence demonstrates that PBM significantly improves outcomes and safety while reducing cost by macroeconomic magnitudes. Despite its huge potential to improve healthcare systems, PBM is not yet adopted broadly. The aim of this study is to analyze the collective experiences of a diverse group of PBM implementors across countries reflecting different healthcare contexts and to use these experiences to develop a guidance for initiating and orchestrating PBM implementation for stakeholders from diverse professional backgrounds.
\end{abstract}

Methods: Semi-structured interviews were conducted with 1-4 PBM implementors from 12 countries in Asia, Latin America, Australia, Central and Eastern Europe, the Middle East, and Africa. Responses reflecting the drivers, barriers, measures, and stakeholders regarding the implementation of PBM were summarized per country and underwent qualitative content analysis. Clustering the resulting implementation measures by levels of intervention for PBM implementation informed a PBM implementation framework.

Results: A set of PBM implementation measures were extracted from the interviews with the implementors. Most of these measures relate to one of six levels of implementation including government, healthcare providers, funding, research, training/education, and patients/public. Essential cross-level measures are multi-stakeholder communication and collaboration.

\footnotetext{
* Correspondence: anke.holtorf@health-os.com

${ }^{\dagger}$ Axel Hofmann, Donat R. Spahn and Anke-Peggy Holtorf contributed equally to this work.

${ }^{3}$ Health Outcomes Strategies GmbH, Colmarerstrasse 58, CH4055 Basel,

Switzerland

${ }^{4}$ Faculty of the College of Pharmacy, University of Utah, Salt Lake City, UT,

USA

Full list of author information is available at the end of the article
}

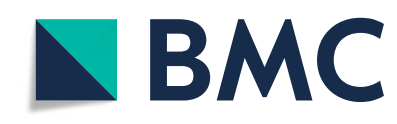

(c) The Author(s). 2021 Open Access This article is licensed under a Creative Commons Attribution 4.0 International License, which permits use, sharing, adaptation, distribution and reproduction in any medium or format, as long as you give appropriate credit to the original author(s) and the source, provide a link to the Creative Commons licence, and indicate if changes were made. The images or other third party material in this article are included in the article's Creative Commons. licence, unless indicated otherwise in a credit line to the material. If material is not included in the article's Creative Commons licence and your intended use is not permitted by statutory regulation or exceeds the permitted use, you will need to obtain permission directly from the copyright holder. To view a copy of this licence, visit http://creativecommons.org/licenses/by/4.0/ The Creative Commons Public Domain Dedication waiver (http://creativecommons.org/publicdomain/zero/1.0/) applies to the data made available in this article, unless otherwise stated in a credit line to the data. 
Conclusion: The implementation matrix resulting from this research helps to decompose the complexity of PBM implementation into concrete measures on each implementation level. It provides guidance for diverse stakeholders to design, initiate and develop strategies and plans to make PBM a national standard of care, thus closing current practice gaps and matching this unmet public health need.

Keywords: Patient blood management, Transfusion, Patient outcomes, Practice change, Culture change, Implementation

\section{Background}

Of the millions of patients hospitalized yearly, a large proportion is anemic at admission. Preoperative anemia rates range from 20 to $75 \%$ [1], and hospital acquired anemia often adds to the problem [2]. In most cases, anemia is not considered a clinically significant condition, remains unnoticed, and therefore uncorrected in hospitalized patients.

However, a large body of evidence shows that anemia, blood loss, and transfusion are independent risk factors for adverse outcomes including morbidity, mortality and average length of hospital stay [3-6]. Patient blood management is defined by the WHO as "a set of evidencebased practices to optimize medical and surgical patient outcomes through preservation of the patient's own blood" [7]. The International Foundation for Patient Blood Mangement specifies, that "Patient Blood Management (PBM) is an evidence-based bundle of care to optimize medical and surgical patient outcomes by clinically managing and preserving a patient's own blood" [8]. Patient blood management rests on three pillars: diagnosis and treatment of anaemia (especially iron deficiency anaemia), minimization of blood loss, and avoidance of unnecessary transfusions. In addition to being a fundamental element of good clinical practice in transfusion, it plays a key role in primary health care. The multi-professional, multimodal, and individualized approach involves general practitioners, hematologists, anesthesiologists, intensive care specialists, surgeons, and others. The term 'Patient Blood Management' was coined in 2005 [9], but the concept has been emerging since a much longer time $[10,11]$. Meanwhile, large multicentric observational studies and randomized controlled trials demonstrated that Patient Blood Management significantly improves morbidity, mortality, and average length of hospital stay, while reducing overall cost of care [12-15]. Clinical thought leaders urge that Patient Blood Management should be implemented as standard of care, and reduction of allogeneic blood product utilization should serve as a marker for success [16, 17]. In 2010, the World Health Organization (WHO) endorsed Patient Blood Management [18] and the fourth Strategic Objective of the "WHO Action framework for blood products 2020-2023' released in February 2020 calls for 'Effective implementation of patient blood management' [7].

However, despite compelling evidence and ongoing WHO policy drive, practical guidance for healthcare providers and national authorities [16, 19-21] and clinical guidelines and recommendations across numerous specialties and national health systems [17, 22-30], implementation of Patient Blood Management is still far behind the expectations for good and safe clinical practices.

The implementation of Patient Blood Management is hampered by barriers mostly related to the difficulty of changing traditional "physicians' attitudes" towards transfusion [31] and "transfusion behavior" [32-34]. Even hard-hitting crises such as the HIV-pandemic in the 1970s and 1980s with tens of thousands infected from contaminated donor blood, the huge death toll, billions of dollars in financial losses from lawsuits and compensations and criminal charges [35] only had a transient impact on changing long standing transfusion practice [36]. What was called at the time "transfusion alternative strategies" showed compelling results and could have been helpful to reduce overall blood utilization with similar outcomes [37-40], but went largely unnoticed [3]. Instead, the focus remained solely on improving blood product safety through introducing donor blood testing methods with unprecedented cost per quality adjusted life year (QALY) between 4.7 and 11.2 million US-\$, representing 94-224 times the then commonly accepted threshold in public health decision making (50,000 US-\$/QALY) [41, 42]. Meanwhile, and despite rapidly accumulating clinical evidence for adverse transfusion outcomes and favorable Patient Blood Management outcomes [43], numerous Patient Blood Management guidelines [17, 22-30], WHO endorsement [18], call for Patient Blood Management [7], and several national policy recommendations, the global implementation of Patient Blood Management is still alarmingly slow. Huge inter-center and inter-country transfusion variability indicates, that blood utilization is rather driven by culture and behavior than evidence $[33,34$, 44-46].

Continuing to ignore the cumulative evidence puts life, well-being and safety of millions of hospitalized patients 
at risk. Delaying Patient Blood Management implementation also means that healthcare systems forego savings of macro-economic magnitudes from a system-wide implementation of Patient Blood Management [15]. This is even more alarming in countries striving towards Universal Healthcare Coverage and with severe resource constraints. In 2016, Eichbaum et al. compared the Patient Blood Management implementation status in four countries using a six-questions survey and observed considerable variation between countries driven both by differences in health contexts and disparities in resources [47]. They concluded that comparing Patient Blood Management strategies across low-, middle-, and highincome countries should foster mutual learning and implementing innovative, evidence-based strategies for improvement.

Following this recommendation, a more in-depth questionnaire was developed in this study to gather, through interviews, the experiences of a diverse group of implementors of Patient Blood Management across countries with different economic and healthcare contexts. The first aim was to describe the status-quo and chosen implementation approach in each of the surveyed countries, and to extract the drivers, barriers, measures, and stakeholders to be involved. The second aim of the study was to analyze this information and synthesize it into an implementation framework for Patient Blood Management which can serve as a comprehensive guidance how to implement Patient Blood Management.

\section{Methods}

Semi-structured interviews mostly lasting 45-60 min were conducted between November 2019 and May 2020 with a multi-disciplinary group of 36 Patient Blood Management implementors leading the implementation of Patient Blood Management in their respective environment. Ten countries from Latin America, Central and Eastern Europe, Asia, Middle East and Africa were selected to reflect experiences from countries with different levels and types of healthcare resources and system (national/ private funders, public / private providers), and different developmental stages of Patient Blood Management (from early stage to more advanced). In addition, Australia was chosen as a reference country, where Patient Blood Management is adopted broadly and supported through public health authorities since 2008 and through National Patient Blood Management Guidelines since 2009 [15, 48, 49]. Likewise, a Swiss reference case was included, where Patient Blood Management is sustainably implemented across a leading hospital (University Hospital of Zürich). All interviewees were actively involved in implementing
Patient Blood Management, and they were selected from the network of the authors, the International Foundation Patient Blood Management [50], and the local networks of the industry or other interviewees. The selection aimed to represent different clinical disciplines (e.g., hematologists, anesthesiologists, surgeons) and perspectives (e.g., clinical specialists, blood bank, policy, Patient Blood Management coordinator, industry). All interviews followed the structure of a newly developed questionnaire (Additional File 1). One question required rating of predefined barriers between 0 (not important) and 4 (very important). To allow the respondent to provide potentially unexpected answers, all other nine questions were formulated open without prompting specific answers. The survey was piloted with 11 interviewees and then fully rolled-out after minor improvements in language and sequence of questions (survey flow). Most interviews were conducted via web-communication (GoToMeeting $^{\mathrm{TM}}$ ) by a single interviewer (AP Holtorf, Dr. rer. nat, female, without pre-existing relationship to the interviewees) in English language, two interviews were conducted by a second qualified male interviewer in Chinese language after detailed briefing by the main interviewer. The interview questionnaire was provided to the interviewees at least 1 week before the interviews. During the interviews, the interviewees verbally consented to note-taking, recording, and publication of the results. The notes were revised using the recordings and the interviewees had the opportunity to review, correct or complement their initial responses. The COREQ checklist was applied to document transparent reporting of this interview-based qualitative study and the completed form is available as Additional File 2 [51]. Qualitative content analysis was performed for analysis and synthesis following published guidance [52, 53]: 1.) Responses per country were extracted to a structured summary document (from two to four interviews per country except for Switzerland with one). 2.) Responses from all countries regarding status-quo, approach of the implementation, and 3.) drivers, barriers, measures, and stakeholders for Patient Blood Management were transferred in an electronic spreadsheet and coded guided by the items mentioned by the interviewees (grounded theory approach). 4.) The coded responses from step three were evaluated for the frequency of mentions (frequency analysis). 5.) Accelerating and inhibiting factors were pooled and translated into implementation measures (re-coding). 6.) Using an axial coding approach [54], the measures were classified by the interventional levels (policy/government, funding, research, healthcare provision, training/education, and public / patients). Steps 1 to 5 were conducted by the 
Table 1 Demographics of the interviewees. (1 expert could represent more than 1 perspectives. Therefore, the numbers in the columns can add up to more than the number of experts). The survey was piloted with representatives of pharmaceutical companies being actively involved in Patient Blood Management (Abdi Ibrahim, Genesis Pharma, Hikma, Sandoz Pharma, Takeda, Vifor Pharma)

\begin{tabular}{|c|c|c|c|c|c|c|c|c|c|c|c|c|c|}
\hline & Australia & Brazil & China & Croatia & Greece & Lebanon & Mexico & $\begin{array}{l}\text { Saudi } \\
\text { Arabia }\end{array}$ & $\begin{array}{l}\text { South } \\
\text { Africa }\end{array}$ & $\begin{array}{l}\text { South } \\
\text { Korea }\end{array}$ & Turkey & $\begin{array}{c}\text { Switzer- } \\
\text { land }\end{array}$ & Total \\
\hline & AUS & BRA & CHN & HRV & GRE & LBN & MEX & SAU & ZAF & KOR & TUR & CHE & \\
\hline Number of Interviews & 3 & 3 & 2 & 3 & 4 & 3 & 4 & 4 & 2 & 4 & 3 & 1 & 36 \\
\hline Hematologist & 1 & 2 & & & 1 & & & 4 & 2 & 1 & & & 11 \\
\hline Anesthesiologist & & & 1 & 3 & 1 & 1 & 1 & & & & 2 & 1 & 10 \\
\hline Blood bank & & 1 & & & 2 & & & 4 & 1 & 1 & & & 9 \\
\hline Surgeon & 1 & & & & 1 & & 1 & & & 3 & 1 & & 7 \\
\hline Obstetrics Gynecology & & & 1 & & & 2 & 1 & & & & 1 & & 5 \\
\hline Critical Care & & & & & & & 2 & & & & 1 & & 3 \\
\hline Cardiovascular Medicine & & & & & & & 1 & & & & 1 & & 2 \\
\hline \multicolumn{2}{|c|}{ Public Health / Health research } & & & & & & 1 & & & & 1 & & 2 \\
\hline Ministry of Health & & & & & & & & & & 1 & 1 & & 2 \\
\hline Nurse & 1 & & & & & & & & & & & & 1 \\
\hline Laboratory Medicine & & & & & & & & & & 1 & & & 1 \\
\hline Engineer & & 1 & & & & & & & & & & & 1 \\
\hline Patient advocate & & 1 & & & & & & & & & & & 1 \\
\hline $\begin{array}{l}\text { Pharmaceutical Industry } \\
\text { (Pilot Interviews) }\end{array}$ & 1 & 1 & 1 & 1 & 1 & 1 & 1 & & 1 & 1 & 1 & 1 & 11 \\
\hline
\end{tabular}

main interviewer and step 6 collaboratively by the authors.

\section{Results}

\section{Demographics}

Thirty-six Patient Blood Management implementors, named "Patient Blood Management Implementation Group" with 15 women and 21 men from 12 countries, were interviewed following 11 pilot interviews (total of 47). The respective perspectives are depicted in Table 1.

\section{Current status and approach in implementing patient blood management (question 3)}

The country-level responses for the current level of $\mathrm{Pa}$ tient Blood Management implementation and the approaches (top-down, bottom-up, or both approaches simultaneously) are summarized in Table 2. Australia, after initial bottom-up implementation in several leading public and private institutions, has fully implemented Patient Blood Management supported by national institutions including the National Blood Authority (NBA), the Australian Commission on Safety and Quality in Healthcare, the Western Australia Department of Health, and the Australian Red Cross Blood Service. In South Korea, Patient Blood Management was implemented in few institutions about a decade ago, followed by a broader strategic approach supported by national authorities. In China, Turkey and Mexico, Patient Blood Management implementation originated with leading clinicians ("champions") of large national institutions and is now increasingly recognized by the authorities. In South Africa, the implementation of Patient Blood Management is led by the South African National Blood
Service and supported by a national Patient Blood Management expert group [21].

Croatia, Greece and Lebanon seek the dual pathway, although the current political situation in Lebanon has put all governmental support to a halt. Brazil, Saudi Arabia, and Switzerland currently rely on local clinician-led initiatives (bottom-up).

\section{Drivers for the implementation of patient blood management (question 7A)}

Of the 11 drivers mentioned unprompted during the interviews (Fig. 1), patient outcomes (26 mentions), cost savings (23 mentions), preventing or better dealing with blood shortages (16 mentions from Sth. Korea, Turkey, Mexico, China, Brazil), improving patient safety or reducing complications (15 mentions from Brazil, China, Sth. Korea, Saudi Arabia, Turkey) were quoted most frequently. Several experts also mentioned national policy [8], education and awareness (concerning the risks of transfusion and benefits of Patient Blood Management) [7], and a quality assurance system [6].

Shorter length of hospital stays, better use of resources, and reduction of waste were only mentioned once each. Patient demand was considered to become a driver once the risks related to transfusion and the benefits Patient Blood Management were recognized more broadly in the general population.

\section{Barriers for the Implementation of patient blood management (question 6)}

Except for Australia, where Patient Blood Management is already widely adopted into practice, the need to change work practice was rated as the most prominent 


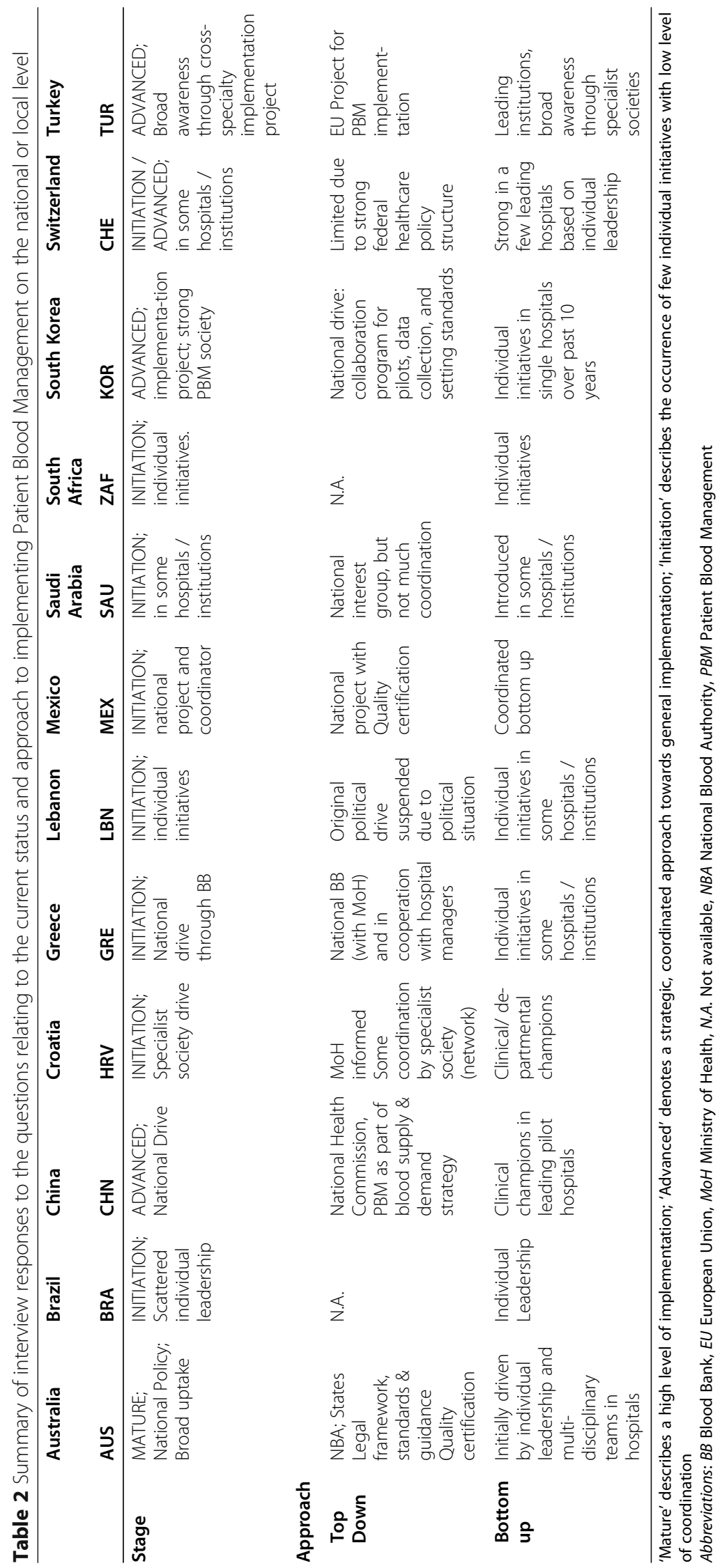


barrier for the implementation of Patient Blood Management as shown in Table 3. The need for collaboration and communication was rated equally important across the countries, followed by the lack of experience with $\mathrm{Pa}$ tient Blood Management, the feasibility to integrate Patient Blood Management into the current processes, and strong belief in transfusion.

\section{Accelerators and inhibitors for the implementation of patient blood management (question 7E)}

The responses for factors accelerating or supporting Patient Blood Management implementation fell into 24 categories as shown in Fig. 2 (left part). Generation of local data and evidence, education and training for Patient Blood Management, a national Patient Blood Management policy, and strong thought leadership, were the most frequently mentioned factors. Blood scarcity, funding, awareness of transfusion risks, incentives for Patient Blood Management engagement, belief and commitment of care personnel, and quality assurance obligation were also frequently mentioned. During the final six interviews between February and May 2020, the COVID-19 pandemic was newly mentioned as potential accelerator due to increased blood scarcity and potential blood safety issues.

The inhibitors or delaying factors fell into 22 categories (see Fig. 2, right part) with the most frequently mentioned being low awareness, no funding for set-up cost, education gaps, and stickiness of the old practice (even stronger if combined with the responses for the closely related resistance against change), lack of interdisciplinary commitment, and resistance against change.

\section{Stakeholders (question 7B)}

Sixty-three percent of the interviewees (29 of 46) identified policy makers (National Health Council, Ministry of Health, etc.) as important stakeholders in Patient Blood Management implementation. As shown in Fig. 3, the majority also listed either specialists in general [22], or specific specialists $(12 \mathrm{x}$ anesthesiologists, $7 \mathrm{x}$ hematologists, $5 \mathrm{x}$ surgeons), 35\% (16 of 46) included the hospital management. Other stakeholders (professional societies, national or regional blood banks, payers, nursing staff, enthusiastic champions, hospital pharmacists, patients/ patient organizations, pharmaceutical companies, researchers/academics, hospital champion, general practitioners were mentioned less frequently or only in other parts of the interview (medical schools, nongovernmental organizations, or the public at large).

\section{Coding and clustering of implementation measures}

After translating accelerators and inhibitors into actionable measures and clustering these measures by the type (level) of intervention, six levels for intervention were identified: government/policy, funding, research,

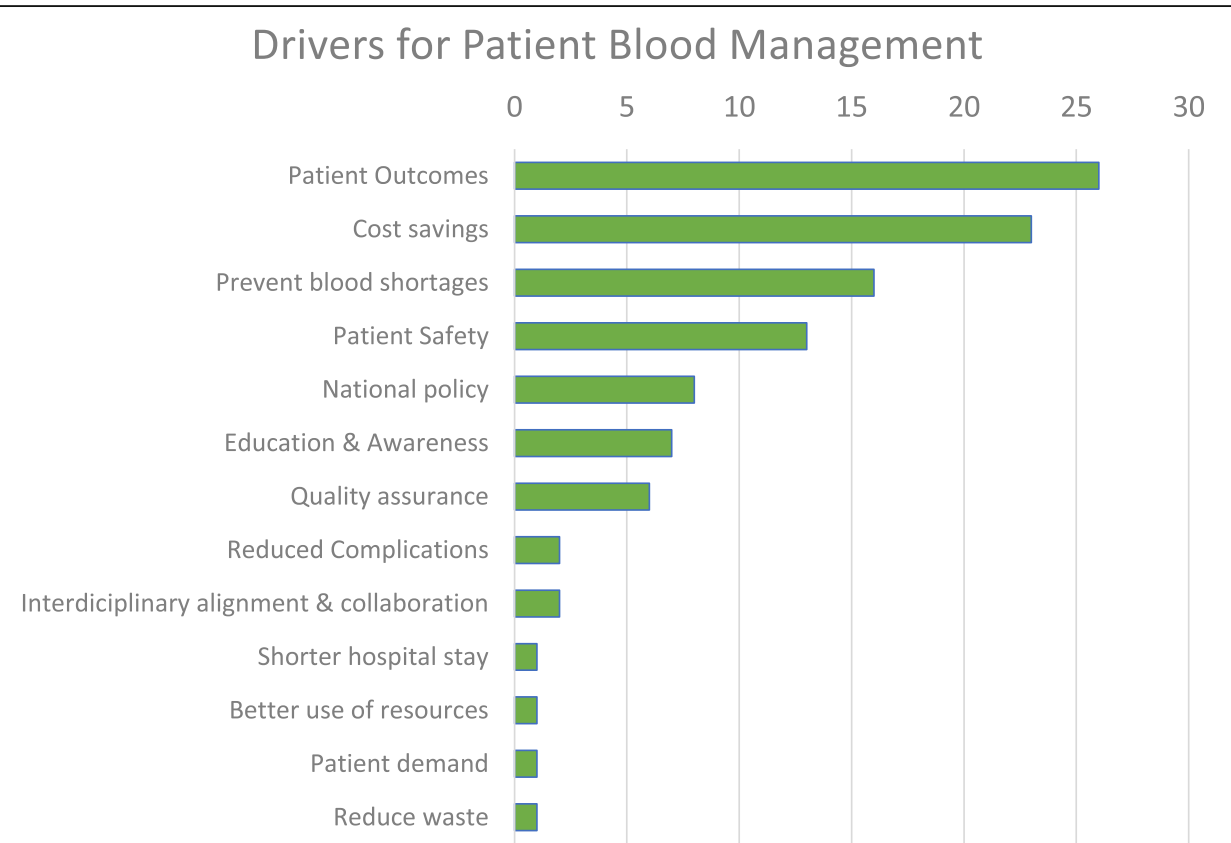

Fig. 1 Drivers for Patient Blood Management. Quantitative evaluation of all drivers mentioned by the interviewees when asked the question" What could be the main drivers for Patient Blood Management - Why is Patient Blood Management needed?". The responses were spontaneous and unprompted. $(N=46)$ The driving factors were sorted by the total number of mentions (top to bottom decreasing). Note: The number of mentions is not a measure for the strength of a specific driver. Education \& Awareness is abbreviated for 'education and awareness relating to the risks of transfusion and the benefits of Patient Blood Management' 
Table 3 Rating of Barriers for Implementation by perceived severity of the barrier. The rating was between 0 (is no barrier) and 4 (high barrier). The barriers were sorted by the average rating (top to bottom decreasing). ( $N=35)$ Color coding: red for average country values of 3 or higher, white for values between 2.01 and 2.99, and green for values of 2 or lower

\begin{tabular}{|c|c|c|c|c|c|c|c|c|c|c|c|c|c|c|}
\hline Barriers & Australia & Brazil & China, PR & Croatia & Greece & Lebanon & Mexico & Saudi Arabia & Sth Africa & Sth Korea & Switzerland & Turkey & Average & STDev \\
\hline Change of work practice & 1.0 & 3.7 & 3.5 & 3.3 & 3.3 & 3.3 & 3.8 & 3.0 & 3.5 & 2.5 & 3.0 & 3.3 & 3.1 & 0.74 \\
\hline Collaboration / communication & 4.0 & 3.0 & 4.0 & 2.5 & 3.5 & 3.3 & 1.8 & 3.3 & 3.0 & 2.8 & 2.0 & 3.0 & 3.0 & 0.69 \\
\hline No / limited PBM experience & 3.0 & 3.0 & 2.0 & 2.5 & 2.7 & 3.0 & 2.5 & 3.3 & 3.3 & 3.3 & 4.0 & 2.5 & 2.9 & 0.52 \\
\hline Process / Feasibility & 3.5 & 3.0 & 3.0 & 3.0 & 2.0 & 3.0 & 2.5 & 2.5 & 3.0 & 3.3 & 3.0 & 2.2 & 2.8 & 0.44 \\
\hline Strong belief in transfusion & 0.5 & 2.7 & 1.0 & 3.5 & 1.8 & 3.0 & 4.0 & 2.8 & 3.0 & 3.8 & 3.0 & 3.0 & 2.7 & 1.06 \\
\hline Number of staholders & 1.5 & 2.7 & 0.0 & 2.8 & 2.5 & 4.0 & 2.3 & 2.8 & 2.0 & 1.5 & 2.0 & 3.7 & 2.3 & 1.05 \\
\hline Cost & 0.5 & 3.0 & 2.5 & 2.5 & 2.0 & 4.0 & 2.5 & 1.8 & 2.0 & 2.5 & 2.0 & 1.5 & 2.2 & 0.85 \\
\hline Sustainability & 2.5 & 1.0 & 0.0 & 2.0 & 1.3 & 2.7 & 1.0 & 2.3 & 1.0 & 1.8 & 3.0 & 2.0 & 1.7 & 0.87 \\
\hline 'Competition' w. other interventions & 0.5 & 1.3 & 1.0 & 0.0 & 1.5 & 0.7 & 1.0 & 1.8 & 2.0 & 1.8 & 2.0 & 1.7 & 1.3 & 0.64 \\
\hline
\end{tabular}

healthcare providers, education/training, and public/patients. On each of the six levels specific measures can contribute to the implementation of Patient Blood Management as reflected in Table 4 with reference to the concrete examples reported by the implementors.

\section{Discussion}

\section{The challenge}

Unless translated into the daily routine and organizational culture, evidence is of limited value [71]. To bridge the gap and effectuate the necessary culture change, it is essential to understand the drivers and barriers for Patient Blood Management as well as the stakeholders' roles and responsibilities. An essential challenge in replacing the long-standing, well-organized, productcentered culture of transfusion medicine by the patient- centered model of Patient Blood Management is that most diverse stakeholders need to communicate, collaborate and overcome the complexity of the Patient Blood Management implementation process. This starts with their specific contribution to the systemic implementation as summarized into the implementation matrix displayed in Fig. 4, which was derived from the full and detailed collection of measures identified from the interviews (Table 4). We will discuss each level of the table in more detail in the passages following below.

\section{Using the Implementation matrix to develop patient blood management strategies}

The Patient Blood Management-implementation matrix, as derived from the interviews, guides Patient Blood Management implementors in systematically identifying

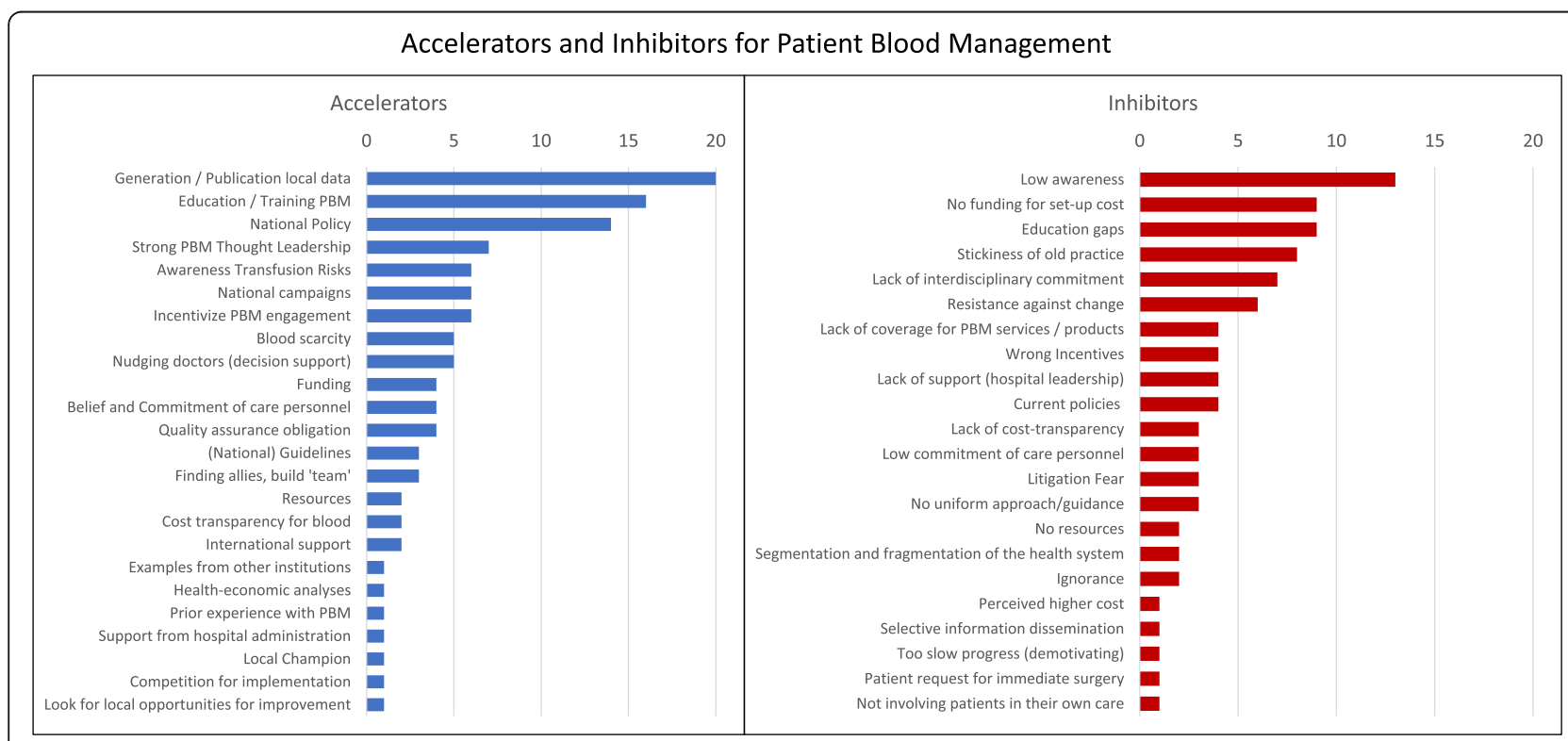

Fig. 2 Accelerators and Inhibitors for Patient Blood Management. Quantitative evaluation of factors mentioned by the interviewees when asked for the factors which would accelerate (Accelerators) or delay or inhibit (Inhibitors) the implementation of Patient Blood Management from their perspective. The responses were spontaneous and unprompted. $(N=46)$ The items were sorted by the total number of mentions (top to bottom decreasing). Note: The number of mentions is not a measure for the strength of a specific accelerator or inhibitor 


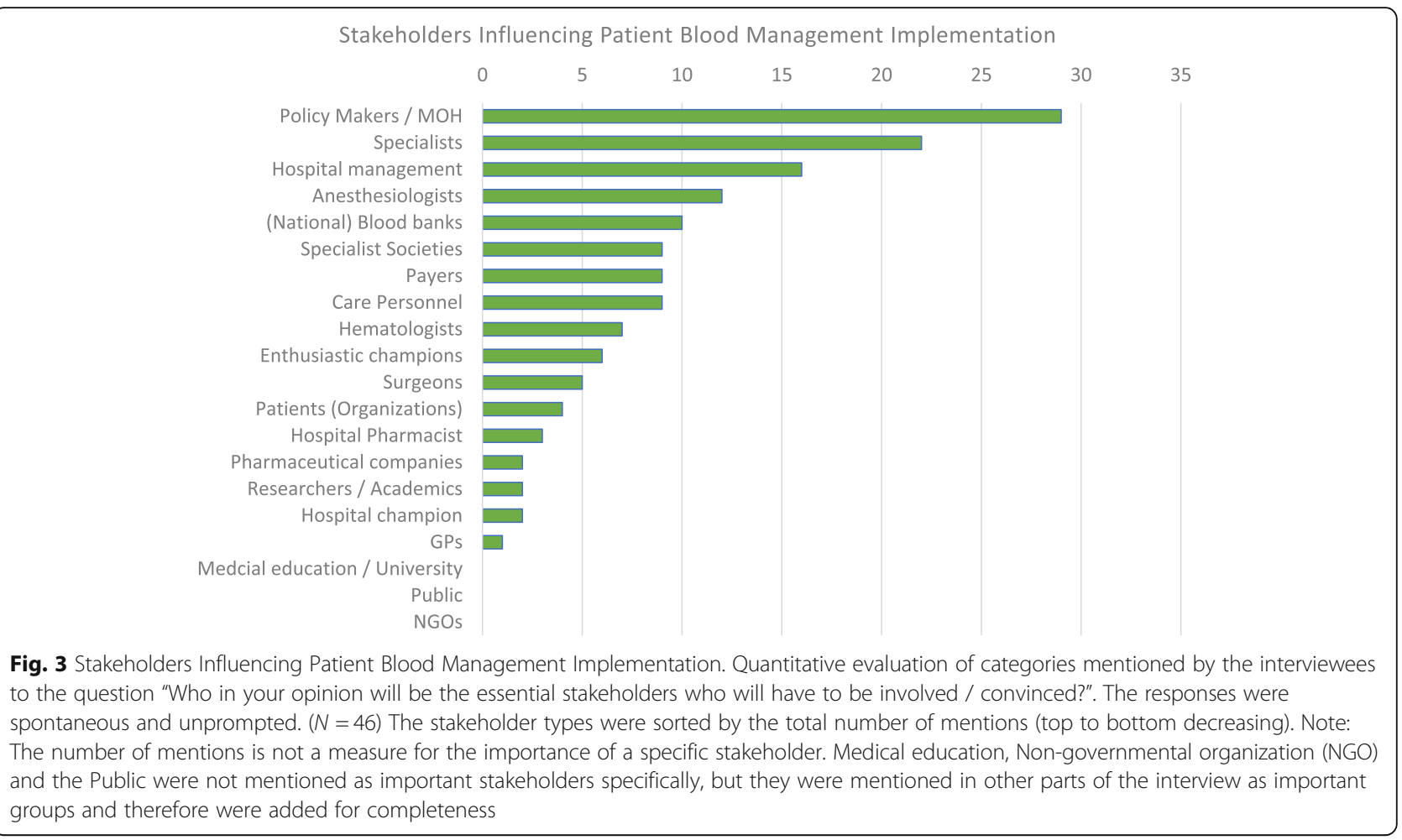

effective measures for Patient Blood Management implementation depending on the economic and healthcare context in their country.

These measures will be discussed in more detail along six implementation levels and consolidated in the final section into a Guided Implementation recommendation.

\section{Government level}

Patient Blood Management is expected to improve quality of care, reduce dependency on donor blood, and contribute to better access to healthcare and equity (evidence-based blood preservation for all patients/citizens in the country). In Western Australia, hospital stays were reduced by almost 70,000 days over 5 years [15]. Suchlike improvement enhances capacity of care and consequently, patient access, and resource utilization. Likewise, the savings due to Patient Blood Management allow for better allocation of scarce resources, thus increasing productivity of the healthcare sector. This should motivate national policy makers to prioritize $\mathrm{Pa}$ tient Blood Management.

National policy makers and senior representatives of the Health Ministry are important stakeholders in coordinating Patient Blood Management implementation nationally (see Fig. 3). Reporting and incentivization of key performance indicators, accreditation of healthcare providers for Patient Blood Management, Patient Blood Management certification of clinicians, and funding and facilitating the development of multi- disciplinary national Patient Blood Management guidelines form essential structural elements for driving Patient Blood Management implementation nation-wide.

However, structural changes on government level usually require long time. One implementor stated "it takes more than seven years to introduce a policy in our country". Creating a sense of urgency through multiple stimuli, including success stories demonstrated in pilots and the generation, publication, or communication of the evidence, can help to overcome the inertness for introducing a new medical model perceived as being complex [10].

\section{Healthcare provider level}

Patient Blood Management offers the rare opportunity to improve patient outcomes while reducing resource utilization and cost $[15,72,73]$. The healthcare provider related measures reported by the implementors start with the identification of local champions and allies from clinical and non-clinical departments to create the sufficient momentum and mass for the implementation. The securing of funding, information technology (IT) infrastructure and support to enable Patient Blood Management data collection, reporting and benchmarking was deemed equally necessary as establishing multiprofessional teams, Patient Blood Management committees, program coordinators and nurses. As recommended previously by others $[19,61]$ and aligned with 
Table 4 Summary of measures to consider for implementing PBM, sorted by level of intervention: Government (national and/or regional), funding, research, healthcare provision, training/education, and patients

\begin{tabular}{|c|c|c|c|}
\hline Measures & Rational / Expectations & Examples & Points to consider \\
\hline \multicolumn{4}{|c|}{ GOVERNMENT LEVEL (national or regional) } \\
\hline National Policy & $\begin{array}{l}\text { - National initiatives and guidance push } \\
\text { the hospitals towards PBM } \\
\text { implementation }\end{array}$ & $\begin{array}{l}\text { - AUS: National policy for PBM and } \\
\text { national measures to support } \\
\text { implementation } \\
\text { - TUR, KOR: Close collaboration of PBM } \\
\text { leaders with MoH } \\
\text { - TUR: qualification for a 3-yr EU grant } \\
\text { dedicated to a systematic country- } \\
\text { wide implementation of PBM [55] } \\
\text { - CHN: officially addressed the } \\
\text { importance of PBM to improve clinical } \\
\text { practice [56] }\end{array}$ & $\begin{array}{l}\text { CHALLENGES } \\
\text { - Changing of policy priorities; political } \\
\text { instability (LBN) } \\
\text { - Policy priority of shifting from tertiary } \\
\text { hospitals to primary care level } \\
\text { antagonizes the pre-operative PBM in- } \\
\text { terventions (CHN) } \\
\text { - National policy not a game changer in } \\
\text { countries with decentralized healthcare } \\
\text { (CHE) }\end{array}$ \\
\hline Blood Shortage & $\begin{array}{l}\text { - Actual and anticipated blood shortage is } \\
\text { recognized on a policy level and } \\
\text { requires action; donation volume is } \\
\text { shrinking, the demand for blood is } \\
\text { increasing (aging population) } \\
\text { - Donor deferrals due to new or re- } \\
\text { emerging pathogens; cancelled blood } \\
\text { collections due to lockdown during } \\
\text { epidemics } \\
\text { - Family replacement schemes: mandatory } \\
\text { donations may increase risk and limit } \\
\text { access }\end{array}$ & $\begin{array}{l}\text { - ZAF, CHN, MEX: Frequent supply issues } \\
\text { - HRV, GRE: Seasonal shortages } \\
\text { - KOR, ZAF: Shortage and COVID-19 virus } \\
\text { risk }^{\mathrm{a}} \\
\text { - BRA: Zika-Virus [57]; supply issues in } \\
\text { public system } \\
\text { - AUS, TUR: Shortage predicted } \\
\text { - LBN, GRE, MEX: Replacement modus } \\
\text { - CHN: 30\% Reciprocal blood donation }\end{array}$ & $\begin{array}{l}\text { REMARK } \\
\text { - Impact of COVID-19 pandemic on } \\
\text { blood supply [58] }\end{array}$ \\
\hline $\begin{array}{l}\text { Strong PBM } \\
\text { Thought } \\
\text { Leadership }\end{array}$ & $\begin{array}{l}\text { - Fosters a broader country-wide accept- } \\
\text { ance and change } \\
\text { - Liaise on policy level, engage with } \\
\text { payers, engage specialist societies, and } \\
\text { introduce medical curricula }\end{array}$ & $\begin{array}{l}\text { - KOR: Korean PBM Society with multi- } \\
\text { disciplinary leadership function } \\
\text { - TUR: EU-funded project for PBM imple- } \\
\text { mentation across Turkey }\end{array}$ & $\begin{array}{l}\text { REMARK } \\
\text { - May be difficult for few individuals to } \\
\text { cover that scope and thus, formation } \\
\text { of a high-level work or interest group } \\
\text { may be advisable }\end{array}$ \\
\hline PBM Incentives & $\begin{array}{l}\text { - Attract clinicians to become part of the } \\
\text { change } \\
\text { - Increase level of experience and } \\
\text { familiarity with PBM }\end{array}$ & $\begin{array}{l}\text { - CRO: participation in international } \\
\text { clinical study } \\
\text { - TUR, KOR, MEX, ZAF: National pilots \& } \\
\text { research opportunities }\end{array}$ & $\begin{array}{l}\text { REMARKS } \\
\text { - Involve practitioners actively in } \\
\text { research } \\
\text { - Recognition of individual initiative } \\
\text { through active engagement and } \\
\text { authorship }\end{array}$ \\
\hline $\begin{array}{l}\text { National } \\
\text { Guidelines }\end{array}$ & $\begin{array}{l}\text { - Adapting international guidelines to } \\
\text { local healthcare context can be essential } \\
\text { for acceptance } \\
\text { - National guidance will facilitate } \\
\text { coordinated and homogeneous activities }\end{array}$ & $\begin{array}{l}\text { - ZAF, TUR, KOR, MEX, BRA, HRV, CHN: } \\
\text { ongoing projects to locally adapt } \\
\text { international guidelines }\end{array}$ & $\begin{array}{l}\text { RISK } \\
\text { - Scattered / fragmented approaches } \\
\text { will make it difficult to consolidate in } \\
\text { best practice }\end{array}$ \\
\hline
\end{tabular}

\section{FUNDING LEVEL}

Alignment of policy and funding

Reimbursement $\quad$ Increase the willingness to invest in establishing PBM

- Adjust reimbursement systems to incentivize improved health outcomes and efficiency and disincentivize transfusion volume $[59,60]$.

Cost transparency • Mandate full cost transparency of for blood; Cost transfusion and PBM to allow for cost'fairness' effective allocation of (public) funds
- KOR: Center for Disease Control in the $\mathrm{MoH}$ and the Health Insurance and Reimbursement Agency (HIRA) committed to PBM related projects (1) auditing the current level of transfusion appropriateness in each hospital, and (2) funding dedicated projects on PBM implementation in the country

- KOR, MEX, AUS, TUR: Funding national pilot or full implementation projects - BRA: volume-dependent reimbursement to hospitals (fee for service) incentivizes a high use of transfusions: but first examples of capitation-based hospital reimbursement emerge (supportive for PBM)

- GRE, HRV: Not knowing the cost of blood products or artificially low cost impedes adoption of PBM

\section{CHALLENGE}

- Heterogeneity in access to healthcare and its funding requires different approaches for funding and reimbursement of PBM (MEX, LBN)

\section{CHALLENGES}

- Potential other sources of funding (NGOs, special international projects)

- Funding always compromised during (economic) crises

\section{REMARK}

- Even if at zero cost to the hospital, blood products are not for free from a 
Table 4 Summary of measures to consider for implementing PBM, sorted by level of intervention: Government (national and/or regional), funding, research, healthcare provision, training/education, and patients (Continued)

\begin{tabular}{|c|c|c|c|}
\hline Measures & Rational / Expectations & Examples & Points to consider \\
\hline & & & societal perspective \\
\hline $\begin{array}{l}\text { Funding and } \\
\text { resources in } \\
\text { hospital }\end{array}$ & $\begin{array}{l}\text { - Secure funding necessary for setting up } \\
\text { the infrastructure (including point-of- } \\
\text { care testing devices, cell salvage equip- } \\
\text { ment, pre-operative anemia clinic, con- } \\
\text { tinuous medical education (CME) and } \\
\text { training } \\
\text { - Identify and remove dis-incentives }\end{array}$ & $\begin{array}{l}\text { - HRV, GRE, LBN, MEX: Difficulties in } \\
\text { securing funding despite principal } \\
\text { support for the concept } \\
\text { - BRA, LBN: Fee for service dis- } \\
\text { incentivizes PBM (imbalance between } \\
\text { profitability and patient health) } \\
\text { - Alignment across budgets: e.g. } \\
\text { pharmacy budget vs other cost }\end{array}$ & $\begin{array}{l}\text { REMARK } \\
\text { - Use measures / local data to } \\
\text { demonstrate the realistic budget } \\
\text { needs, ROI, time frame required [61]. }\end{array}$ \\
\hline
\end{tabular}

\section{RESEARCH LEVEL}

Quality

measurement/ assurance

Collecting and publishing local data
- Use of quality measures, to track blood use (i.e., units ordered, used, and discarded per hospital, ward, type of intervention and individual specialists) to shift focus to patient needs and outcomes

- Demonstrating impact of PBM with local data on clinical outcomes, adverse events or complications,

- Capturing and reporting local epidemiology data (prevalence)

- Quantify opportunities, risks, and cost for PBM in the local setting; ideally as multidisciplinary intra- or inter-hospital collaboration

Health-economic • To convince stakeholders of the costanalyses

International support and collaboration effectiveness of PBM, analyses must be based on local data (cost / outcomes)

- Cross-fertilize and share the learnings transnationally
- KOR, MEX, CHE, AUS: pursuing quality and performance measurement initiatives

- AUS, CHE, KOR: local data collection systems initiated or established to enable reporting, benchmarking, or

- TUR: publication of local data [62]

- Health-economic evidence from AUS, $\mathrm{CHE}, \mathrm{GER}$, and the USA $[63,64]$ performance analysis
- International collaboration is frequent, e.g. strong engagement of IFPBM \& SABM, ZAF w. National Blood Authority in AUS, KOR w. AUS, BRA w. SABM.
REMARK

- Performance measures empowers local transfusion committees and PBM implementation task forces

REMARKS

- Local evidence helps to refute that the international experience may not be transferrable to the local context

- Local research motivates participants to gain expertise and to become part of the change

\section{CHALLENGE}

- Current H/E evidence from countries with specific economic and healtheconomic settings and may not be generalizable

REMARK

- Includes international teaching, webbased services, advisory exchange, or involvement of experts in another country's task forces.

\section{HEALTHCARE PROVIDER LEVEL}

Communication $\quad$ Strengthen belief and commitment of clinical staff

- Re-align all stakeholders around the transfusion process

Identify allies,

- To increase clout and trust across specialties

build teams

- Foster multi-disciplinary collaboration, mutual endorsement and support

Prior experience with PBM

- Expand the knowledge and openness for PBM by involving care personnel from different disciplines in implementation projects

Ensure support from hospital administration
- Design/align the organization to enable optimal and sustainable PBM across specialties

- Secure funding for staff, systems support
- GRE: Generation of an intra-hospital consensus and protocol with reporting system for restrictive blood use - MEX, ZAF, AUS: continuous communication, involvement, and hospital,

- ZAF, MEX: Chat-group in a social media platform to report local experiences, announce events, and post relevant publications, questions. and suggestions

- LBN: Expanding across specialties already in initial phase added great impetus MEX, TUR: Multidisciplinary PBM Academies; LEB, KOR, ZAF: Multidisciplinary Iron Academies

- Pilot projects in several hospitals/wards to involve and expose them to PBM methods

- Most initiatives reported that alignment with hospital administration / CEO was improving chances for success feedback by coordinator / initiator in
A common vision and buy-in by those who need to change their practice is essential to achieve change [65]

REMARKS

- PBM is a team effort $[15,21,61]$

- Supports forming a guiding coalition [65]

REMARK

- Overcome the stickiness of the old practice [66] and resistance to change

REMARKS

-While small changes could be introduced individually or within one specialty the full potential can only be 
Table 4 Summary of measures to consider for implementing PBM, sorted by level of intervention: Government (national and/or regional), funding, research, healthcare provision, training/education, and patients (Continued)

\begin{tabular}{|c|c|c|}
\hline Measures & Rational / Expectations & Examples \\
\hline & $\begin{array}{l}\text { (IT), other resources } \\
\text { - Get approval to establish a multi- } \\
\text { disciplinary PBM committee }\end{array}$ & $\begin{array}{l}\text { - HRV, GRE: Activities under } \\
\text { departmental responsibility may not } \\
\text { need agreement by hospital } \\
\text { management. } \\
\text { - LBN, SAU, HRV, LBN: To get funding fo } \\
\text { establishing PBM was difficult and } \\
\text { therefore done within the existing } \\
\text { resources (overtime) } \\
\text { - BRA, MEX: dedicated project } \\
\text { management ensures planning and } \\
\text { roll out across specialties / } \\
\text { departments }\end{array}$ \\
\hline $\begin{array}{l}\text { Local champion } \\
\text { (Medical Director } \\
\text { or project } \\
\text { coordinator for } \\
\text { PBM) }\end{array}$ & $\begin{array}{l}\text { - Responsible for planning, organizing and } \\
\text { directing PBM, supporting specialists, } \\
\text { and ensuring continuous data collection, } \\
\text { reporting and benchmarking, }\end{array}$ & $\begin{array}{l}\text { - HRV, GRE, MEX: general role in training } \\
\text { education, information, protocol } \\
\text { development } \\
\text { - BRA: Change management } \\
\text { - AUS, CHE: organize PBM at patient } \\
\text { level (case management) }\end{array}$ \\
\hline $\begin{array}{l}\text { Hospital } \\
\text { protocols (SOPs) }\end{array}$ & $\begin{array}{l}\text { - Tailor PBM protocols to the specific } \\
\text { hospital context and routines } \\
\text { - Increase local ownership across the } \\
\text { disciplines, interdisciplinary commitment }\end{array}$ & $\begin{array}{l}\text { - HRV, GRE, TUR, MEX, BRA: Several } \\
\text { interviewees reported the } \\
\text { development of local protocols before } \\
\text { the availability of National Guidelines }\end{array}$ \\
\hline $\begin{array}{l}\text { Data collection, } \\
\text { reporting \& } \\
\text { benchmarking } \\
\text { system }\end{array}$ & $\begin{array}{l}\text { - Shows impact, measures gaps, and helps } \\
\text { to improve quality of care }\end{array}$ & $\begin{array}{l}\text { - ZAF, KOR: currently developing a } \\
\text { monitoring system in hospital(s) }\end{array}$ \\
\hline $\begin{array}{l}\text { Nudging } \\
\text { clinicians \& } \\
\text { stimulating } \\
\text { competition }\end{array}$ & $\begin{array}{l}\text { - Using IT or quality reporting systems to } \\
\text { motivate and remind physicians to } \\
\text { practice PBM } \\
\text { - Using the competitive nature of people } \\
\text { to motivate them to excel in PBM }\end{array}$ & $\begin{array}{l}\text { - AUS, CHF, MEX, ZAF reported use or } \\
\text { plan to use competitive forces or } \\
\text { 'nudging instruments' to remind } \\
\text { practitioners to improve their PBM } \\
\text { practices (reminders, league tables) }\end{array}$ \\
\hline
\end{tabular}

\section{Points to consider}

achieved with multi-disciplinary

change

- Understand the economic and system incentives and to be in close

communication to collaboratively identify the path to implementation (milestones, tasks, and responsibilities)

\section{REMARK}

- PBM coordinator can be a success factor for sustainability (AUS, CHE)

REMARKS

- Include IT and/or quality specialists in developing the local procedures for mapping into data collection and analytical support tools

- Nudging = nonregulatory and nonmonetary interventions that steer people in a particular direction while preserving their freedom of choice" $[67,68]$

REMARK

- Includes nursing, hospital pharmacy, blood ordering process to ensure common goals

- GRE: Importance of aligning the ordering of blood products.

\section{TRAINING \& EDUCATION LEVEL}

Seizing local - Create momentum: Use opportunities in opportunities for own environment for starting with improvement specific aspects of PBM

- Move forward faster and prove success

- HRV, LBN: Start within ward/ department

- ZAF: start with communication \& education of hospital specialists - MEX, BRA: pilots

Education and Training for PBM

- Identify and address knowledge gaps among specialists

- Update under-and postgraduate curricula

- AUS: Integration in medical school (University of Western Australia) curriculum \& exams

- MEX, ZAF, TUR: PBM academies and/or continued medical education (CME) for practitioners

- AUS, ZAF: online training material [69]

REMARK

- Even small 'wins' will motivate people

REMARKS

- Training of all specialists concerned (incl. anesthesiologist, intensive care specialists, surgeons, hematologists, oncologists, gastroenterologists, obstetricians \& gynecologists) and nursing staff in relation to benefits of PBM,

- Avoid asymmetry in information to prevent that 'eminence wins over evidence' in the choice of therapy

Increase $\quad$ Overcome eminence-based practice Awareness Transfusion Risks
- Overcome eminence-based practice
("transfusion is always beneficial") and in-
crease the knowledge about the associated risks
- Global: Many of the specialists who administer transfusions during surgery (surgeons, anesthesiologists) often don't see the mid-or long-term
REMARKS

- Necessitates re-education of all participants in the transfusion decision

- Requires information, education, and 
Table 4 Summary of measures to consider for implementing PBM, sorted by level of intervention: Government (national and/or regional), funding, research, healthcare provision, training/education, and patients (Continued)

\begin{tabular}{|c|c|c|c|}
\hline Measures & Rational / Expectations & Examples & Points to consider \\
\hline & & $\begin{array}{l}\text { complications (infections, immune re- } \\
\text { actions, thrombosis). }\end{array}$ & $\begin{array}{l}\text { reminders across specialties } \\
\text { (publications and newsletters, } \\
\text { conferences, social media-channels) }\end{array}$ \\
\hline $\begin{array}{l}\text { Medico-legal } \\
\text { aspects and } \\
\text { protective } \\
\text { measures as part } \\
\text { of PBM training }\end{array}$ & $\begin{array}{l}\text { - Strengthen the assertiveness of } \\
\text { physicians relating to PBM }\end{array}$ & $\begin{array}{l}\text { BRA: Litigation is commonly used by } \\
\text { patients to get access to procedures } \\
\text { which they perceive to be beneficial }\end{array}$ & \\
\hline \multicolumn{4}{|c|}{ PATIENT \& PUBLIC LEVEL } \\
\hline $\begin{array}{l}\text { National } \\
\text { information } \\
\text { campaigns }\end{array}$ & $\begin{array}{l}\text { - Develop awareness for PBM } \\
\text { - Encourage patients to discuss PBM at } \\
\text { their doctor's appointment } \\
\text { - Prevent litigation against physicians } \\
\text { following guideline-compliant restrictive } \\
\text { transfusion strategies } \\
\text { - Decrease patient demand blood } \\
\text { transfusion }\end{array}$ & $\begin{array}{l}\text { - KOR, LBN, ZAF: Initiated or conducted } \\
\text { national awareness campaigns through } \\
\text { important media channels } \\
\text { - BRA: Litigation is commonly used by } \\
\text { patients to get access to procedures } \\
\text { which they perceive to be beneficial }\end{array}$ & $\begin{array}{l}\text { RISKS } \\
\text { - If done too early, doctors might be } \\
\text { overwhelmed by patient demand } \\
\text { - Too much information on transfusion } \\
\text { risks may negatively impact the } \\
\text { willingness of the public to donate } \\
\text { blood } \\
\text { REMARK } \\
\text { - Involving patients, collaborating with } \\
\text { patients, and informing the public may } \\
\text { improve understanding and reduce } \\
\text { the risk for litigation }\end{array}$ \\
\hline PAG initiatives & $\begin{array}{l}\text { - Co-create national information cam- } \\
\text { paigns (PBM thought leaders, politicians, } \\
\text { PAGs) } \\
\text { - Explore patient experiences and } \\
\text { preferences } \\
\text { - Engagement / advocating for PBM } \\
\text { insurance coverage } \\
\text { - Achieve comprehensive patient } \\
\text { education on risks and benefits of all } \\
\text { treatment options (including transfusion) } \\
\text { for anaemia, blood loss and } \\
\text { coagulopathy } \\
\text { - Ensure fully informed consent and/or } \\
\text { shared decision making } \\
\text { - PAGs to request PBM certification and/or } \\
\text { hospitals accreditation }\end{array}$ & $\begin{array}{l}\text { - HRV, KOR: Initial contacts } \\
\text { - TUR: In contact with } 5 \text { NGO'S, who } \\
\text { receive regular information } \\
\text { - GRE, LBN, HRV, KOR, BRA: increasing } \\
\text { demand for participatory medicine and } \\
\text { shared decision making by PAGs and/ } \\
\text { or healthcare policy }\end{array}$ & $\begin{array}{l}\text { REMARKS } \\
\text { - PAG-patient interaction relating to } \\
\text { transfusion and/or PBM not yet } \\
\text { common } \\
\text { - Co-creation / co-production: re- } \\
\text { searchers, practitioners and the public } \\
\text { join efforts and share responsibilities to } \\
\text { develop, implement, monitor, evaluate } \\
\text { and re-develop interventions [70] }\end{array}$ \\
\hline
\end{tabular}

Abbreviations: $\mathrm{MoH}$ Ministry of Health, SABM, https://sabm.org Society for the Advancement of Blood Management, ROI Return on Investment. Country

Abbreviations: AUS Australia, BRA Brazil, CHN Peoples Republic of China, HRV Croatia, GRC Greece, KOR Republic of Korea, LBN Lebanon, MEX Mexico, ZAF South

Africa, CHE Switzerland, TUR Turkey, PAG Patient Advocacy Group, IFPBM International Foundation Patient Blood Management, SABM Society for the Advancement of Blood Management

aThe risk of COVID-19 viral infection only became apparent starting in January 2020. Hence, this threat was only mentioned in the last interviews (KOR, ZAF, SAU)

recognized approaches to change [74, 75], implementors preferred a piloting approach ("harvest low hanging fruit") accompanied by the development of internal capability, aiming to gain practical experience and to optimize the Patient Blood Management processes in the local context. Other important modules on the provider level were developing Patient Blood Management standard operating procedures, defining key performance indicators, and measuring outcomes.

Electronic clinical decision support systems for controlling transfusions were deemed effective, also if combined with systems to incentivize and reward the progression towards Patient Blood Management. Electronic transfusion decision support systems can effectively reduce transfusion rate and index in the daily routine [76, 77] and serve as a 'nudging' mechanism.
'Nudging' denotes "non-regulatory and non-monetary interventions for changing behavior that steer people in a particular direction while preserving their freedom of choice" $[67,68]$. This includes automated or targeted reminders, individual performance reviews based on local data collection and analysis, or Patient Blood Management dashboards as reported elsewhere [78].

\section{Training and education level}

To avoid asymmetry of information and conflicting behaviors within the hospital, training, and communication on Patient Blood Management needs to address the entire clinical staff including clinical specialists, nurses, pharmacists, and others influencing decisions related to managing patients' blood. Implementors suggested that clinical knowledge and skills for Patient Blood 


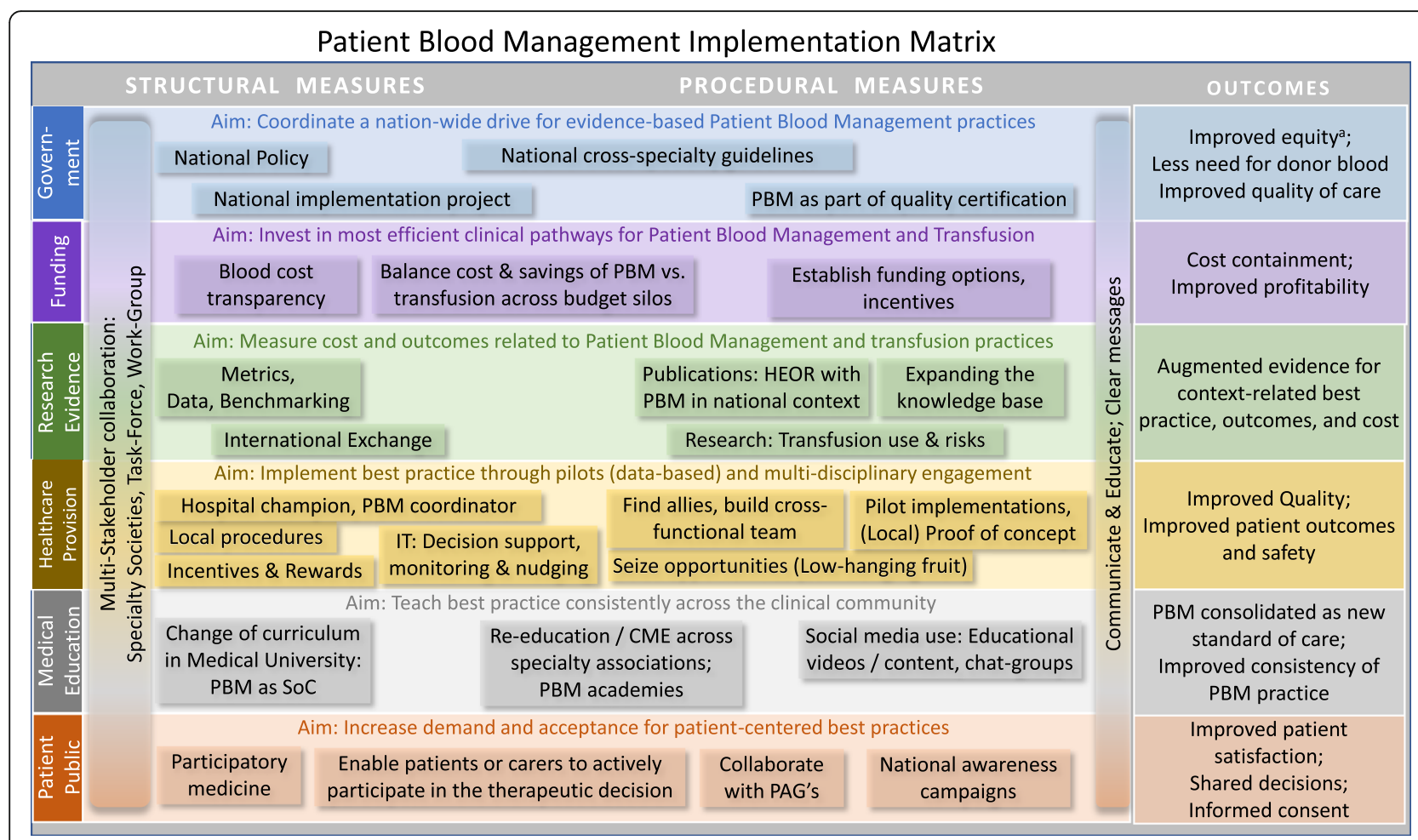

Fig. 4 Patient Blood Management Implementation Matrix. Implementation matrix summarizing the aims, measures, and expected outcomes of comprehensive Patient Blood Management across six implementation levels. This implementation matrix is derived from the full table of measures (Table 4). ${ }^{\text {a) }}$ Equity: access to evidence-based blood preservation for all patients/citizens in the country

Management must be embedded in both under- and postgraduate education (curricula in medical schools, accredited continuous medical education, Patient Blood Management academies, and e-learning- and information-platforms). However, except for Western Australia, Patient Blood Management is currently not part of the undergraduate curriculum of medical students. Like Patient Blood Management preceptorships, educational and training activities for Patient Blood Management are currently organized for post-graduates, often initiated by the implementors and local Patient Blood Management champions, and mostly industry sponsored. Implementors should liaise with the leadership of academia and medical schools to firmly integrate Patient Blood Management into the undergraduate education in alignment with the federal Ministries of Health and Education, where applicable.

\section{Research level}

Patient Blood Management offers a broad spectrum of new experimental, clinical, epidemiological, and healtheconomic research opportunities, as evidenced by the growing number of research publications. Benchmarking and reporting of key performance indicators for Patient Blood Management yield valuable insights concerning clinical and economic outcomes related to Patient Blood
Management. Further research as well as national and international exchange will help to improve Patient Blood Management techniques as also highlighted by international thought leaders $[29,61,78,79]$. Most importantly, as an essential prerequisite, the implementors demanded to generate and communicate local evidence (prove of outcomes and cost-effectiveness in the local context at local cost structures) to link the implementation across hospitals and to foster policies on the national level.

\section{Funder level}

Public funders may benefit from Patient Blood Management through reduced average length of hospital stay and lower resource consumption, resulting in cost containment and better resource use. Private funders may expect higher profitability, in particular with diagnosis related groups (DRG) or value-based reimbursement systems (e.g., accountable care): in DRGs with high anemia prevalence and potentially high blood loss such as obstetrics, cardiovascular surgery or oncology, the total cost per episode of care have shown to decrease over time, thus leading to reduced tariffs [80]. For Germany, overall yearly cost-savings with elective surgery were calculated to be $€ 1029$ million - almost $1.58 \%$ of the total national hospital budget [81]. 
Even in fee-for-service settings, funders may benefit from Patient Blood Management: currently, they might reimburse hospitals for the number of transfusions administered, while patients pay for their anemia treatment out-of-pocket. Where transparent, implementors in the interviews reported increasing cost of blood components (per unit) due to increasing measures for quality and safety testing. Once funders begin incentivizing (pre-operative) anemia management as an essential part of $\mathrm{Pa}$ tient Blood Management, they foster better outcomes, fewer complications, and shorter hospital stays, thus reducing the overall reimbursement cost per episode of care as compared to the currently established transfusion preferences $[15,63]$. The cost of quality assurance and administering these blood products is a multifold of the actual acquisition cost and therefore, represents a substantial cost volume for the hospital and consequently for the funder, even where allogeneic blood products are covered by national funds and are considered 'free' [82, 83].

Appropriate reimbursement of Patient Blood Management including anemia management was a strong request in our interviews, and implementors even proposed to incentivize Patient Blood Management for healthcare providers. Given the documented savings potential with Patient Blood Management [15, 64, 81, 8486], it should be a priority for implementors to inform, educate and engage funders on this important issue. Following the example of the German health insurance BARMER [80], insurers may even help underpinning the Patient Blood Management value using their own data to demonstrate savings with improved outcomes.

\section{Patient level}

According to the implementors, Patient Blood Management and its benefits are largely unknown to patients, despite being the 'big winners' from Patient Blood Management with significantly improved clinical outcomes, safety, and reduced average length of hospital stay. Patients usually seek medical treatment based on a proper diagnosis and expect to be treated with safe and effective medical or surgical interventions. Unless being informed by their treating physician and being involved for shared decision making, they would not know that Patient Blood Management improves their chances for earlier discharge from hospital and reduces their risk for hospital acquired infection or even mortality. Patient advocates could contribute by creating Patient Blood Management awareness, but also by educating for and defending patients' rights. Collaborating and likewise, supporting national campaigns to emphasize safety and the beneficial outcomes of Patient Blood Management, could foster shared clinical decision making and informed consent. Some implementors even saw the potential for patient advocates to approach funders to incentivize and support Patient Blood Management.

Potential risks were expected by one implementor when entering the public domain too early and thus, creating demand before physicians would be sufficiently familiar with Patient Blood Management and its benefit. Another implementor cautioned, that too much information on transfusion risks may negatively impact on the willingness to donate blood. Involvement of patients or patient advocates should be planned thoroughly within the country culture and context. However, the aim to involve patients more in their own care [87], the strive for 'person-centered healthcare' [88], and the priority of increased patient safety [89-91] conforms to physicians' obligations towards educating and informing patients about all risks and benefits of available treatment options. Medicolegal experts increasingly caution that widespread disregard of transfusion associated risks for adverse outcomes may result in litigation against those neglecting physicians and specialists [92]. Informing the public and the patients in collaboration with patient advocacy groups can be a powerful element of the Patient Blood Management implementation strategy. Engaging the public and patients will not only result in more demand for Patient Blood Management but also improve patient satisfaction and foster participatory medicine.

\section{Guided Implementation}

In some of the countries described in this survey, Patient Blood Management was implemented simultaneously from bottom-up (e.g., from a department level or hospital/clinical level) and top-down (driven by policy and/ or hospital administrative leadership) (see Table 2) with large variation in the closeness of the interaction between policy and operational levels. In other countries, implementation progresses just through the bottom-up pathway, predominantly initiated, and led by individuals or small groups with different clinical background or innovation managers. To effectively coordinate and execute a statewide or even national implementation project across all six interdependent layers requires governance $[15,20,93]$. Following the example of Western Australia $[15,93]$, the EU Guide for Health Authorities [20] suggests that National Patient Blood Management Steering Committees, preferably under the authority of the Health Ministry, should coordinate planning and provisioning of Patient Blood Management resources, structural requirements, and national and international Patient Blood Management research efforts. Transitional tasks forces were proposed to develop national Patient Blood Management reimbursement schemes and managing Patient Blood Management transition costs (i.e. 
costs to manage the 'paradigm shift'). Likewise, National Patient Blood Management Steering Committees could facilitate broad and homogeneous adoption, supported by national programs or committees for guidelines development, data collection, benchmarking, and analytics.

The experiences and expectations of the implementors confirmed the importance of adapting to the local healthcare and cultural context and aligning with the local / national healthcare priorities and funding situation. Implementation success depends on good change strategies. Resistance from the old transfusion paradigm due to ignorance and conflicting incentives needs to be overcome, and the Patient Blood Management paradigm must be anchored in the healthcare delivery culture. Future research, for example with proponents of the transfusion priority, could further investigate the motivation for such resistance and possible ways to overcome it.

Kotter's model for managing change embraces eight essential accelerators: establishing a sense of urgency, creating a guiding coalition, developing a change vision, communicating the vision for buy-in, empowering broad-based action, generating short-term wins, never letting up, and incorporating changes into the culture $[65,94]$. This should be considered regardless of where implementation starts, whether on a national, regional or hospital level, or initiated by a blood bank. Concurrent action, well adapted to the local context, across all eight change accelerators while rapidly building a network of change agents should maximize its adoption and impact [65]. For example, for a clinician it is probably easiest to start the process in the own specialty, which is within her or his own control. However, even at that stage, it would be good to design an implementation plan aiming for broader implementation. An example for a stepwise implementation starting on the hospital level is available in the online material as a part of a slide show summarizing the key findings of this manuscript (Additional File 3, slide 8). Of course, careful planning the implementation is indispensable when aiming at wider adoption of Patient Blood Management.

The implementation matrix (Fig. 4) may serve as a guidance in planning, even if starting with a small pilot. Following Realist Evaluation approach [95] the user should see the matrix as a 'menu' of elements for designing the local implementation. On each level, the implementors need to assess what works (best) in the local context, when, and which stakeholders should be involved for successfully creating the implementation path for Patient Blood Management in the country or organization.

Adaptation to the local context depends on access to and inclusion of the key stakeholders and influencers within the own healthcare environment. Implementors need to identify the stakeholders in implementing
Patient Blood Management and understand what motivates each of them to support, engage, or contribute [19-21].

\section{Limitations}

The following limitations should be considered for this research. The selected countries cannot be fully representative for all countries and healthcare systems across the world. However, they were from five continents and included healthcare systems of high or lower income, and the interviewees were professionals leading and/or promoting Patient Blood Management in the healthcare sector of their respective environment. The latter may also be a limitation of the study as we did not interview stakeholders who are opposing the adoption of Patient Blood Management. A survey with these groups could help to better understand and address potential resistance or opposition. The impact of the various implementation measures across six levels could not be determined. Once Patient Blood Management will be established in more countries and healthcare systems, key performance indicators might be linked to specific measures and rated, thus showing their relative importance.

\section{Conclusion}

With the objective of learning from the practical experiences with the implementation of Patient Blood Management, structured interviews were conducted with a multidisciplinary group of Patient Blood Management implementors in 12 countries reflecting initial, advanced, and full level of implementation. There was consensus that patients would benefit most from Patient Blood Management, with improved outcomes including morbidity, mortality, quality of life, average length of hospital stay, and patient safety. The expected improvements in outcomes and cost savings as well as more efficient use of (blood) resources were identified as the core drivers. The need for changing work practice and for collaboration and communication and the lack of experience with Patient Blood Management were rated as most important barriers for Patient Blood Management. After converting the identified accelerators and inhibitors for Patient Blood Management into actionable implementation measures, six levels for intervention were identified, including government, healthcare providers, education, funders, research, and patients. This forms the framework for a six-level implementation matrix, describing all measures and expected outcomes as reported by the implementors.

\footnotetext{
Abbreviations

AUS: Australia; BRA: Brazil; CHN: Peoples Republic of China; HRV: Croatia;

GRC: Greece; KOR: Republic of Korea; LBN: Lebanon; MEX: Mexico;

SAU: Kingdom of Saudi Arabia; ZAF: South Africa; CHE: Switzerland;

TUR: Turkey; CME: Continuing medical education; GP: General practitioner;
} 
LMIC: Low- and middle-income country; MoH: Ministry of Health; PBM: Patient blood management; QoL: Quality of life; SoC: Standard of care; WHO: World Health Organization

\section{Supplementary Information}

The online version contains supplementary material available at https://doi. org/10.1186/s12913-021-06484-3 .

\section{Additional file 1. \\ Additional file 2. \\ Additional file 3.}

\section{Acknowledgements}

- All interviewed implementors are represented in the 'PBM Implementation Group':

- James ISBISTER, Australia

- Jeff HAMDORF, Australia

- Linda CAMPBELL, Australia

- Bruno BENITES, Brazil

- Gustavo DUARTE, Brazil

- Guillermo RABELLO, Brazil

- Hongwen Jl, China

- Lihui WEI, China

- Visnja IVANCAN, Croatia

- Natasa KOVAC, Croatia

- Tina TOMIC MAHECIC, Croatia

- Chara MATSOUKA, Greece

- Bairaktari AGGELIKI, Greece

- Gafou ANTHI, Greece

- Alexandros CHARALABOPOULOS, Greece

- David ATTALAH, Lebanon

- Samia JEBARA, Lebanon

- Rabih CHAHINE, Lebanon

- Ángel Augusto PÉREZ CALATAYUD, Mexico

- Ángel Fernando GALVAN GARCIA, Mexico

- Miguel AYALA, Mexico

- Bettina TORRES PÉREZ, Mexico

- Jong Hoon PARK, Republic of Korea

- YoungWoo KIM, Republic of Korea

- Jeong Jae LEE, Republic of Korea

- Tae Hyun UM, Republic of Korea

- Hind A.AL-HUMAIDAN, Saudi Arabia

- Ammar AL SUGHAYIR, Saudi Arabia

- Khalid BATARFI, Saudi Arabia

- Salwa HINDAWI, Saudi Arabia

- Vernon LOUW, South Africa

- Jackie THOMPSON, South Africa

- Neslihan ALKIS, Turkey

- Serdar GUNAYDIN, Turkey

- Berrin GUNAYDIN, Turkey

We would like to thank Dr. Anna Mezzacasa \& Anthony Nash from Vifor Pharma for critical discussion and facilitating the interviews through their international network, and we thank the responders for the pilot phase from the pharmaceutical companies as listed in the paper.

\section{Authors' contributions}

$\mathrm{APH}$ and $\mathrm{AH}$ conceptualized the research plans. DRS plaid a critical role in testing and improving the interview flow. APH conducted and evaluated all interviews. $\mathrm{APH}, \mathrm{AH}$ and DRS were major contributors in writing the manuscript. All authors read and approved the final manuscript.

\section{Funding}

The research and analysis for this manuscript was funded by Vifor Pharma AG, Switzerland. The funding body played no role in the design of the study and collection, analysis, and interpretation of data and in writing the manuscript. Staff members of the funding body supported the identification of interviewees through sharing their network of country contacts. None of the interviewees received any type of compensation for their time and input.

\section{Availability of data and materials}

The results are presented in aggregated form. The original data are accessible through the corresponding author on reasonable request. The interview questionnaire is available as additional online material (Additional File 1).

\section{Declarations}

\section{Ethics approval and consent to participate}

No ethical approval was sought because the research did not entail systematic collection or analysis of data in which human beings are exposed to manipulation, intervention, or observation (WHO Manual (Section XV.2)). All interviewees were professionals who were informed about and agreed to the purpose of the interviews before and at the beginning of the interview; their verbal consent was recorded. No personal data beyond the interviews with the implementors were used. The interview guide underwent internal compliance review by the pharmaceutical company interviewee in each of the participating countries.

\section{Consent for publication}

Not applicable.

\section{Competing interests}

$\mathrm{AH}$ received honoraria and/or travel support from Celgene (Belgium), Instrumentation Laboratories/Werfen (USA), G1 Therapeutics (USA), the South African National Blood Service and Vifor Pharma, Switzerland.

DRS's academic department is receiving grant support from the Swiss National Science Foundation, Berne, Switzerland, the Swiss Society of Anesthesiology and Reanimation (SGAR), Berne, Switzerland, the Swiss Foundation for Anesthesia Research, Zurich, Switzerland, Vifor SA, Villars-surGlâne, Switzerland. DRS is co-chair of the ABC-Trauma Faculty, sponsored by unrestricted educational grants from Novo Nordisk Health Care AG, Zurich, Switzerland, CSL Behring GmbH, Marburg, Germany, LFB Biomédicaments, Courtaboeuf Cedex, France and Octapharma AG, Lachen, Switzerland. DRS received honoraria / travel support for consulting or lecturing from: Danube University of Krems, Austria, US Department of Defense, Washington, USA, European Society of Anesthesiology, Brussels, BE, Korean Society for Patient Blood Management, Seoul, Korea, Korean Society of Anesthesiologists, Seoul, Korea, Network for the Advancement of Patient Blood Management, Haemostasis and Thrombosis, Paris, France, Baxalta Switzerland AG, Volketswil, Switzerland, Bayer AG, Zürich, Switzerland, B. Braun Melsungen AG, Melsungen, Germany, Boehringer Ingelheim GmbH, Basel, Switzerland, Bristol-MyersSquibb, Rueil-Malmaison Cedex, France and Baar, Switzerland, CSL Behring $\mathrm{GmbH}$, Hattersheim am Main, Germany and Berne, Switzerland, Celgene International II Sàrl, Couvet, Switzerland, Daiichi Sankyo AG, Thalwil, Switzerland, Ethicon Sàrl, Neuchâtel, Switzerland, Haemonetics, Braintree, MA, USA, Instrumentation Laboratory (Werfen), Bedford, MA, USA, LFB Biomédicaments, Courtaboeuf Cedex, France, Merck Sharp \& Dohme, Kenilworth, New Jersey, USA, PAION Deutschland GmbH, Aachen, Germany, Pharmacosmos A/ S, Holbaek, Denmark, Photonics Healthcare B.V., Utrecht, Netherlands, Pfizer AG, Zürich, Switzerland, Pierre Fabre Pharma, Alschwil, Switzerland, Roche Diagnostics International Ltd., Reinach, Switzerland, Sarstedt AG \& Co., Sevelen, Switzerland and Nümbrecht, Germany, Shire Switzerland GmbH, Zug, Switzerland, Tem International GmbH, Munich, Germany, Vifor Pharma, Munich, Germany, Neuilly sur Seine, France and Villars-sur-Glâne, Switzerland, Vifor (International) AG, St. Gallen, Switzerland, Zuellig Pharma Holdings, Singapore, Singapore.

APH is employed by Health Outcomes Strategies GmbH (Switzerland) and has consulted and advised several pharmaceutical companies including Vifor Pharma AG, Novartis, and Abbott Laboratories. Health Outcomes Strategies $\mathrm{GmbH}$ has received funding for this research and for writing the manuscript.

\section{Author details}

${ }^{1}$ Institute of Anesthesiology, University and University Hospital of Zurich, Zurich, Switzerland. 'University of Western Australia Faculty of Health and Medical Sciences, Perth, Australia. ${ }^{3}$ Health Outcomes Strategies GmbH, Colmarerstrasse 58, CH4055 Basel, Switzerland. ${ }^{4}$ Faculty of the College of Pharmacy, University of Utah, Salt Lake City, UT, USA. 
Received: 20 November 2020 Accepted: 6 May 2021 Published online: 02 July 2021

\section{References}

1. Muñoz M, Gómez-Ramírez S, Kozek-Langeneker S, Shander A, Richards T, Pavía J, et al. "Fit to fly": overcoming barriers to preoperative haemoglobin optimization in surgical patients. Br J Anaesth. 2015;115(1):15-24. https://doi. org/10.1093/bja/aev165

2. Krishnasivam D, Trentino KM, Burrows S, Farmer SL, Picardo S, Leahy MF, et al. Anemia in hospitalized patients: an overlooked risk in medical care. Transfusion. 2018;58(11):2522-8. https://doi.org/10.1111/trf.14877.

3. Isbister JP, Shander A, Spahn DR, Erhard J, Farmer SL, Hofmann A. Adverse blood transfusion outcomes: establishing causation. Transfus Med Rev. 2011; 25(2):89-101 [cited 2020 Feb 25]. Available from: http://www.sciencedirect. com/science/article/pii/S0887796310000829.

4. Refaai MA, Blumberg N. The transfusion dilemma--weighing the known and newly proposed risks of blood transfusions against the uncertain benefits. Best Pract Res Clin Anaesthesiol. 2013;27(1):17-35. https://doi.org/10.1016/j. bpa.2012.12.006

5. Vamvakas EC, Blajchman MA. Transfusion-related mortality: the ongoing risks of allogeneic blood transfusion and the available strategies for their prevention. Blood. 2009;113(15):3406-17. https://doi.org/10.1182/blood-2 008-10-167643

6. Farmer SL, Towler SC, Leahy MF, Hofmann A. Drivers for change: Western Australia Patient Blood Management Program (WA PBMP), World Health Assembly (WHA) and Advisory Committee on Blood Safety and Availability (ACBSA). Best Pract Res Clin Anaesthesiol. 2013;27(1):43-58 [cited 2019 Sep 20]. Available from: http://www.sciencedirect.com/science/article/pii/S1521 689612000882

7. World Health Organization. WHO Action framework to advance universal access to safe, effective and quality assured blood products. 2020-2023; 2020. p. 48. [cited 2020 Feb 25]. Available from: https://www.who.int/publica tions-detail/action-framework-to-advance-uas-bloodprods-978-92-4-00003 8-4

8. IFPBM. What is patient blood management? (International Foundation for Patient Blood Management). International Foundation for Patient Blood Management. [cited 2020 Mar 11]. Available from: https://www.ifpbm.org/ knowledge/what-is-patient-blood-management

9. Farmer SL, Isbister J, Leahy MF. History of blood transfusion and patient blood management. In: Transfusion-free medicine and surgery: Wiley; 2014 p. 1-18. [cited 2020 Apr 21]. Available from: https://www.onlinelibrary.wiley. com/doi/abs/10.1002/9781118554685.ch1

10. Farmer S. A brief history of patient blood management in western Australia. Western Australia Patient Blood Management Group; 2019.

11. Isbister JP. The paradigm shift in blood transfusion. Med J Aust. 1988;148(6): 306-8. https://doi.org/10.5694/j.1326-5377.1988.tb117840.x

12. Althoff FC, Neb H, Herrmann E, Trentino KM, Vernich L, Füllenbach C, et al. Multimodal patient blood management program based on a three-pillar strategy: a systematic review and meta-analysis. Ann Surg. 2019;269(5):794804 [cited 2020 May 26]. Available from: https://journals.lww.com/anna Isofsurgery/FullText/2019/05000/Multimodal_Patient_Blood_Management_ Program_Based.3.aspx.

13. Froessler B, Palm P, Weber I, Hodyl NA, Singh R, Murphy EM. The important role for intravenous Iron in perioperative patient blood management in major abdominal surgery: a randomized controlled trial. Ann Surg. 2016; 264(1):41-6. https://doi.org/10.1097/SLA.0000000000001646

14. Khalafallah AA, Yan C, Al-Badri R, Robinson E, Kirkby BE, Ingram E, et al. Intravenous ferric carboxymaltose versus standard care in the management of postoperative anaemia: a prospective, open-label, randomised controlled trial. Lancet Haematol. 2016;3(9):e415-25. https://doi.org/10.1016/\$2352-302 6(16)30078-3

15. Leahy MF, Hofmann A, Towler S, Trentino KM, Burrows SA, Swain SG, et al. Improved outcomes and reduced costs associated with a health-systemwide patient blood management program: a retrospective observational study in four major adult tertiary-care hospitals. Transfusion. 2017:57(6): 1347-58. https://doi.org/10.1111/trf.14006

16. Shander A, Van Aken H, Colomina MJ, Gombotz H, Hofmann A, Krauspe R, et al. Patient blood management in Europe. Br J Anaesth. 2012;109(1):55-68 [cited 2019 Sep 25]. Available from: https:/academic.oup.com/bja/article/109/1/55/236570.

17. Aapro M, Beguin Y, Bokemeyer C, Dicato M, Gascon P, Glaspy J, et al. Management of anaemia and iron deficiency in patients with cancer :
ESMO clinical practice guidelines. Ann Oncol. 2018;29 [cited 2019 Sep 25]. Available from: https://orbi.uliege.be/handle/2268/232303.

18. World Health Assembly. Availability, safety and quality of blood products. Geneva: World Health Assembly; 2010. p. 4. [cited 2020 Apr 22]. Report No.: WAH63-11.17. Available from: https://apps.who.int/gb/ebwha/pdf_files/ WHA63/A63_R12-en.pdf

19. Gombotz H, Hofmann A, Norgaard A, Kastner P. Supporting patient blood management (PBM) in the EU - a practical Implementation guide for hospitals. Luxembourg: European Commission - Directorate-General for Health and Food Safety; 2017. p. 67.

20. Hofmann A, Norgaard A, Kurz J, Choorapoikayi S, Meybohm P, Zacharowski $\mathrm{K}$, et al. Building national programmes of Patient Blood Management (PBM) in the EU. A guide for health authorities. Luxembourg: European Commission; 2017. p. 87. [cited 2017 Jun 26]. Available from: https://ec. europa.eu/health/sites/health/files/blood_tissues_organs/docs/2017 eupbm_authorities_en.pdf

21. Thomson J, Hofmann A, Barrett CA, Beeton A, Bellairs GRM, Boretti L, et al. Patient blood management: A solution for South Africa. S Afr Med J. 2019; 109(7):471-6 [cited 2019 Jul 2]. Available from: http://www.samj.org.za/ index.php/samj/article/view/12648.

22. Faraoni D, Meier J, New HV, Van der Linden PJ, Hunt BJ. Patient blood management for neonates and children undergoing cardiac surgery: 2019 NATA guidelines. J Cardiothorac Vasc Anesth. 2019;33(12):3249-63. https:// doi.org/10.1053/j.jvca.2019.03.036 .

23. Goobie SM, Gallagher T, Gross I, Shander A. Society for the advancement of blood management administrative and clinical standards for patient blood management programs. 4th edition (pediatric version). Pediatr Anesth. 2019; 29(3):231-6 [cited 2019 Sep 3]. Available from: https://onlinelibrary.wiley. com/doi/abs/10.1111/pan.13574

24. Kozek-Langenecker SA, Ahmed AB, Afshari A, Albaladejo P, Aldecoa C, Barauskas $G$, et al. Management of severe perioperative bleeding: guidelines from the European society of anaesthesiology: first update 2016. Eur J Anaesthesiol. 2017;34(6):332-95. https://doi.org/10.1097/EJA. 0000000000000630

25. Muñoz M, Stensballe J, Ducloy-Bouthors A-S, Bonnet M-P, De Robertis E, Fornet I, et al. Patient blood management in obstetrics: prevention and treatment of postpartum haemorrhage. A NATA consensus statement Blood Transfus. 2019;17(2):112-36 [cited 2021 Apr 26]. Available from: https://www.ncbi.n/m.nih.gov/pmc/articles/PMC6476742/ .

26. National Blood Authority. Standard 7 and the patient blood management (PBM) guidelines. [cited 2019 Dec 11]. Available from: https://www.blood. gov.au/standard-7-and-patient-blood-management-pbm-guidelines

27. Pagano D, Milojevic M, Meesters MI, Benedetto U, Bolliger D, von Heymann C, et al. 2017 EACTS/EACTA Guidelines on patient blood management for adult cardiac surgery. Eur J Cardiothorac Surg. 2018;53(1):79-111 [cited 2019 Dec 10]. Available from: https://academic.oup.com/ejcts/article/53/1/79/431 6171

28. Patient Blood Management (PBM) guidelines and initiatives - video timeline [cited 2019 Dec 10]. Available from: https://www.youtube.com/watch?v= IkEl4eweVY4

29. Spahn DR, Bouillon B, Cerny V, Duranteau J, Filipescu D, Hunt BJ, et al. The European guideline on management of major bleeding and coagulopathy following trauma: fifth edition. Crit Care. 2019;23(1):98. https://doi.org/10.11 86/s13054-019-2347-3

30. Task Force on Patient Blood Management for Adult Cardiac Surgery of the European Association for Cardio-Thoracic Surgery (EACTS) and the European Association of Cardiothoracic Anaesthesiology (EACTA), Boer C, Meesters MI, Milojevic M, Benedetto U, Bolliger D, et al. 2017 EACTS/EACTA guidelines on patient blood management for adult cardiac surgery. J Cardiothorac Vasc Anesth. 2018;32(1):88-120.

31. Salem-Schatz SR, Avorn J, Soumerai SB. Influence of clinical knowledge, organizational context, and practice style on transfusion decision making. Implications for practice change strategies. JAMA. 1990;264(4):476-83. https://doi.org/10.1001/jama.1990.03450040072034 .

32. Gombotz H, Rehak PH, Shander A, Hofmann A. Blood use in elective surgery: the Austrian benchmark study. Transfusion. 2007;47(8):1468-80. https://doi.org/10.1111/j.1537-2995.2007.01286.x.

33. Meier J, Kozek-Langenecker S, Filipescu D, Pitarch JVL, Mallett S, Martus P, et al. ESA clinical trials network 2012: ETPOS--European transfusion practice and outcome study. Eur J Anaesthesiol. 2013;30(5):199-201. https://doi.org/1 0.1097/EJA.0b013e32835f0052. 
34. Bennett-Guerrero E, Zhao Y, O'Brien SM, Ferguson TB, Peterson ED, Gammie JS, et al. Variation in use of blood transfusion in coronary artery bypass graft surgery. JAMA. 2010;304(14):1568-75. https://doi.org/10.1001/jama.2010.1406 .

35. Weinberg PD, Hounshell J, Sherman LA, Godwin J, Ali S, Tomori C, et al. Legal, financial, and public health consequences of HIV contamination of blood and blood products in the 1980s and 1990s. Ann Intern Med. 2002; 136(4):312-9. https://doi.org/10.7326/0003-4819-136-4-200202190-00011 .

36. OIDP. National blood collection \& utilization survey. HHS.gov. 2005. [cited 2020 Aug 15]. Available from: https://wayback.archive-it.org/3919/201404021 75910/http:/www.hhs.gov/ash/bloodsafety/2005nbcus.pdf

37. Rosengart TK, Helm RE, DeBois WJ, Garcia N, Krieger KH, Isom OW. Open heart operations without transfusion using a multimodality blood conservation strategy in 50 Jehovah's witness patients: implications for a "bloodless" surgical technique. J Am Coll Surg. 1997;184(6):618-29.

38. Spence RK. The status of bloodless surgery. Transfus Med Rev. 1991;5(4): 274-86 [cited 2020 May 23]. Available from: http://www.sciencedirect.com/ science/article/pii/S0887796391702204.

39. Goodnough LT, Maggio P, Hadhazy E, Shieh L, Hernandez-Boussard T, Khari $P$, et al. Restrictive blood transfusion practices are associated with improved patient outcomes. Transfusion. 2014;54(10pt2):2753-9 [cited 2019 Dec 10]. Available from: https://onlinelibrary.wiley.com/doi/abs/10.1111/trf.12723 .

40. Cooley DA. Limited access myocardial revascularization. A preliminary report. Tex Heart Inst J. 1996;23(2):81-4 [cited 2021 Apr 26]. Available from: https://www.ncbi.nlm.nih.gov/pmc/articles/PMC325318/

41. Jackson BR, Busch MP, Stramer SL, AuBuchon JP. The cost-effectiveness of NAT for HIV, HCV, and HBV in whole-blood donations. Transfusion. 2003; 43(6):721-9. https://doi.org/10.1046/j.1537-2995.2003.00392.x .

42. Custer B, Hoch JS. Cost-effectiveness analysis: what it really means for transfusion medicine decision making. Transfus Med Rev. 2009;23(1):1-12. https://doi.org/10.1016/j.tmrv.2008.09.001

43. Klein HG, Hrouda JC, Epstein JS. Crisis in the sustainability of the U.S. blood system. N Engl J Med. 2017;377(15):1485-8.

44. Gombotz H, Rehak PH, Shander A, Hofmann A. The second Austrian benchmark study for blood use in elective surgery: results and practice change. Transfusion. 2014;54(10pt2):2646-57 [cited 2019 Dec 10]. Available from: https://onlinelibrary.wiley.com/doi/abs/10.1111/trf.12687 .

45. Karimi M, Sullivan JM, Lerer T, Hronek C. National trends and variability in blood utilization in paediatric cardiac surgery. Interact Cardiovasc Thorac Surg. 2017;24(6):938-43.

46. Aquina $C T$, Blumberg $N$, Probst $C P$, Becerra AZ, Hensley BJ, Noyes $K$, et al. Large variation in blood transfusion use after colorectal resection: a call to action. Dis Colon Rectum. 2016;59(5):411-8. https://doi.org/10.1097/DCR. 0000000000000588

47. Eichbaum Q, Murphy M, Liu Y, Kajja I, Hajjar L, Sibinga CS, et al. Patient blood management: an international perspective. Anesth Analg. 2016;123(6): 1574-81 [cited 2019 Oct 21]. Available from: insights.ovid.com.

48. Farmer SL, Trentino K, Hofmann A, Semmens JB, Mukhtar SA, Prosser G, et al. A programmatic approach to patient blood management - reducing transfusions and improving patient outcomes. Open Anesthesiol J. 2015; 9(1):6-16 [cited 2019 Dec 16]. Available from: https://openanesthesiajournal. com/NOLUME/9/PAGE/6/.

49. National Blood Authority Austrilia. Patient Blood Management Guidelines | National Blood Authority. 2009. [cited 2019 Dec 10]. Available from: https:// www.blood.gov.au/pbm-guidelines

50. International Foundation Patient Blood Management. [cited 2020 Nov 3]. Available from: https://www.ffpbm.org/

51. Tong A, Sainsbury P, Craig J. Consolidated criteria for reporting qualitative research (COREQ): a 32-item checklist for interviews and focus groups. Int J Qual Health Care. 2007;19(6):349-57. https://doi.org/10.1093/intghc/mzm042

52. Schreier M. Qualitative content analysis in practice. London: SAGE Publications; 2012. ISBN: 978-1-4462-8992-1.

53. Neuendorf KA. The content analysis guidebook. 2nd, reprint ed. London: SAGE Publications; 2016. ISBN: 978-1-4833-1507-2.

54. Corbin J, Strauss A. Basics of qualitative research: techniques and procedures for developing grounded theory. 4th ed. Los Angeles: SAGE Publications, Inc; 2014. p. 456

55. Patient Blood Management Project. [cited 2020 Aug 14]. Report No.: EU funding number: EuropeAid/139230/IH/SER/TR. Available from: https://hasta kanyonetimi.saglik.gov.tr/
56. China's Report on Blood Safety. National health and family planning commission of the PRC. 2016.

57. Benites BD, Rocha D, Andrade E, Godoy DT, Alvarez P, Addas-Carvalho M. Zika virus and the safety of blood supply in Brazil: a retrospective epidemiological evaluation. Am J Trop Med Hyg. 2019;100(1):174-7.

58. Shander A, Goobie SM, Warne MA, Aapro M, Bisbe E, Perez-Calatayud AA, et al. The essential role of patient blood management in a pandemic: a call for action. Anesth Analg. 2020:Publish Ahead of Print [cited 2020 Apr 3]. Available from: https://journals.Iww.com/anesthesia-analgesia/Abstract/ publishahead/The_Essential_Role_of_Patient_Blood_Management_in.9571 9.aspx.

59. Barnum H, Kutzin J, Saxenian H. Incentives and provider payment methods. Int J Health Plann Manag. 1995;10(1):23-45.

60. Fetter RB. Diagnosis related groups: understanding hospital performance. Interfaces. 1991;21(1):6-26 [cited 2020 Feb 29]. Available from: https://www. jstor.org/stable/25061437.

61. Meybohm P, Richards T, Isbister J, Hofmann A, Shander A, Goodnough LT, et al. Patient blood management bundles to facilitate Implementation. Transfus Med Rev. 2017;31(1):62-71. https://doi.org/10.1016/.tmrv.2016.05.012 .

62. Günaydin B, Isik G, Bagcaz S, Inan G, Bozkurt N, Özkurt ZN, et al. Retrospective evaluation of effects of preoperative anaemia treatment in gynaecological and obstetric surgical patients. Turk J Anaesthesiol Reanim. 2020; [cited 2020 Sep 19]. Available from: https:/turkjanaesthesiolreanim. org/en/retrospective-evaluation-of-effects-of-preoperative-anaemia-trea tment-in-gynaecological-and-obstetric-surgical-patients-13799.

63. Trentino KM, Farmer SL, Swain SG, Burrows SA, Hofmann A, lenco R, et al. Increased hospital costs associated with red blood cell transfusion. Transfusion. 2015;55(5):1082-9. https://doi.org/10.1111/trf.12958 .

64. Hofmann A, Ozawa S, Farrugia A, Farmer SL, Shander A. Economic considerations on transfusion medicine and patient blood management. Best Pract Res Clin Anaesthesiol. 2013;27(1):59-68. https//doi.org/10.1016/.bpa.2013.02.001

65. Kotter JP. Accelerate! Harv Bus Rev. 2012;11(November) [cited 2020 Sep 30]. Available from: https://hbr.org/2012/11/accelerate.

66. Elwyn G, Taubert M, Kowalczuk J. Sticky knowledge: a possible model for investigating implementation in healthcare contexts. Implement Sci. 2007; 2(1):44 [cited 2008 Mar 19]. Available from: http://www.implementa tionscience.com/content/2/1/44.

67. Hertwig $R$, Grüne-Yanoff T. Nudging and boosting: steering or empowering good decisions. Perspect Psychol Sci. 2017;12(6):973-86. https://doi.org/1 $0.1177 / 1745691617702496$

68. Thaler RH, Sunstein CR. Nudge: improving decisions about health, wealth, and happiness. Revised \& expanded edition. New York: Penguin Books; 2009. p. 312.

69. Vernon Louw MedEd. YouTube. [cited 2020 Mar 2]. Available from: https:// www.youtube.com/channel/UCQNPWwjn1P4GBb-jPAdt4gQ

70. Hickey G, Richards T, Sheehy J. Co-production from proposal to paper. Nature. 2018:562(7725):29-31.

71. Grol R, Wensing M. What drives change? Barriers to and incentives for achieving evidence-based practice. Med J Aust. 2004;180(S6):S57-60 [cited 2020 Mar 2]. Available from: https://onlinelibrary.wiley.com/doi/abs/10.5694/ j.1326-5377.2004.tb05948.x

72. Frank SM, Thakkar RN, Podlasek SJ, Ken Lee KH, Wintermeyer TL, Yang WW, et al. Implementing a health system-wide patient blood management program with a clinical community approach. Anesthesiology. 2017;127(5): 754-64. https://doi.org/10.1097/ALN.0000000000001851

73. Kaserer A, Rössler J, Braun J, Farokhzad F, Pape H-C, Dutkowski P, et al. Impact of a Patient Blood Management monitoring and feedback programme on allogeneic blood transfusions and related costs. Anaesthesia. 2019:74:1534.

74. Kislov R, Waterman H, Harvey G, Boaden R. Rethinking capacity building for knowledge mobilisation: developing multilevel capabilities in healthcare organisations. Implement Sci. 2014;9(1):166 [cited 2020 Mar 2]. Available from: https://doi.org/10.1186/s13012-014-0166-0

75. Szulanski $\mathrm{G}$. The process of knowledge transfer: a diachronic analysis of stickiness. Organ Behav Hum Decis Process. 2000;82(1):9-27 [cited 2020 Mar 2]. Available from: http://www.sciencedirect.com/science/article/pii/S074 959780092884X

76. Derzon JH, Clarke N, Alford A, Gross I, Shander A, Thurer R. Restrictive transfusion strategy and clinical decision support practices for reducing RBC transfusion overuse. Am J Clin Pathol. 2019:152(5):544-57. 
77. Yerrabothala S, Desrosiers KP, Szczepiorkowski ZM, Dunbar NM. Significant reduction in red blood cell transfusions in a general hospital after successful implementation of a restrictive transfusion policy supported by prospective computerized order auditing. Transfusion. 2014:54(10pt2):2640-5 [cited 2019 Dec 10]. Available from: https://onlinelibrary.wiley.com/doi/abs/10.1111/ trf.12627.

78. Trentino KM, Swain SG, Geelhoed GC, Daly FFS, Leahy MF. Interactive patient blood management dashboards used in Western Australia. Transfusion. 2016;56(12):3140-1. https://doi.org/10.1111/trf.13854 .

79. Mukhtar SA, Leahy MF, Koay K, Semmens JB, Tovey J, Jewlachow J, et al. Effectiveness of a patient blood management data system in monitoring blood use in Western Australia. Anaesth Intensive Care. 2013;41(2):207-15. https://doi.org/10.1177/0310057X1304100210

80. BARMER. BARMER Krankenhausreport 2019 - Patient Blood Management | BARMER. [cited 2020 Jul 15]. Available from: https://www.barmer.de/presse/ bundeslaender-aktuell/bayern/aktuelles/barmer-krankenhausreport-201 9-222130

81. Drabinski T, Zacharowski K, Meybohm P, Rüger AM, Ramirez de Arellano A. Estimating the epidemiological and economic impact of implementing preoperative anaemia measures in the German healthcare system: The health economic footprint of patient blood management. Adv Ther. 2020; 37(8):3515-36. https://doi.org/10.1007/s12325-020-01372-4 .

82. Shander A, Hofmann A, Ozawa S, Theusinger OM, Gombotz H, Spahn DR. Activity-based costs of blood transfusions in surgical patients at four hospitals. Transfusion. 2010;50(4):753-65. https://doi.org/10.1111/j.1537-2 995.2009.02518x.

83. Abraham I, Sun D. The cost of blood transfusion in Western Europe as estimated from six studies. Transfusion. 2012;52(9):1983-8. https://doi.org/1 0.1111/j.1537-2995.2011.03532.x.

84. Kanavos P, Yfantopoulos J, Vandoros C, Politis C. The economics of blood: gift of life or a commodity? Int J Technol Assess Health Care. 2006;22(3): 338-43. https://doi.org/10.1017/S0266462306051233.

85. Meybohm P, Straub N, Füllenbach C, Judd L, Kleinerüschkamp A, Taeuber I, et al. Health economics of patient blood management: a cost-benefit analysis based on a meta-analysis. Vox Sang. 2019;115(2):182-8 Available from: https://onlinelibrary.wiley.com/doi/full/10.1111/vox.12873

86. Kleinerüschkamp A, Meybohm P, Straub N, Zacharowski K, Choorapoikayil S. A model-based cost-effectiveness analysis of patient blood management. Blood Transfus. 2019;17(1):16-26. https://doi.org/10.2450/2018.0213-17 .

87. Beach MC, Sugarman J. Realizing Shared decision-making in practice. JAMA. 2019;322(9):811-2 [cited 2020 Mar 1]. Available from: https://jamanetwork. com/journals/jama/fullarticle/2740056.

88. Nolte E, Merkur S, Anell A, editors. Achieving person-centred health systems: evidence, strategies and challenges (2020): Cambridge University Press; 2020. p. 398. [cited 2020 Aug 17]. (European observatory on health systems and policies series). Available from: https://www.euro.who.int/en/about-us/ partners/observatory/publications/studies/achieving-person-centred-healthsystems-evidence,-strategies-and-challenges-2020

89. ISQua. Patient safety 2030. international society for quality in healthcare. [cited 2020 Mar 2]. Available from: https://www.isqua.org/news/patient-sa fety-2030.html

90. The Joint Commission. Patient safety. [cited 2020 Mar 2]. Available from: https://www.jointcommission.org/resources/patient-safety-topics/patient-sa fety

91. World Health Organisation. Patient safety. WHO. World Health Organization; [cited 2020 Mar 2]. Available from: http://www.who.int/patientsafety/en/

92. Bolcato M, Russo M, Trentino K, Isbister J, Rodriguez D, Aprile A. Patient blood management: The best approach to transfusion medicine risk management. Transfus Apher Sci. 2020:27:102779.

93. Hofmann A, Friedman D, Farmer S. Western Australia patient blood management project 2008-2012: analysis, strategy, Implementation and financial projections. Australia: Western Australia Department of Health; 2007. p. 154

94. Kotter JP. Leading change: why transformation efforts fail. Harv Bus Rev. 1995;5(May-June) [cited 2020 Sep 30]. Available from: https://hbr.org/1995/ 05/leading-change-why-transformation-efforts-fail-2.

95. Pawson R, Tilley N. Realistic evaluation. London: Sage; 1997.

\section{Publisher's Note}

Springer Nature remains neutral with regard to jurisdictional claims in published maps and institutional affiliations.

\section{Ready to submit your research? Choose BMC and benefit from}

- fast, convenient online submission

- thorough peer review by experienced researchers in your field

- rapid publication on acceptance

- support for research data, including large and complex data types

- gold Open Access which fosters wider collaboration and increased citations

- maximum visibility for your research: over $100 \mathrm{M}$ website views per year

At $\mathrm{BMC}$, research is always in progress.

Learn more biomedcentral.com/submissions 